\title{
LA POLONIA DEL MEDIODÍA: UN TÓPICO POLACO EN LA HISTORIA ESPAÑOLA
}

\author{
por \\ JuAN FERNÁNDEZ-MAYORALAS PALOMEQUe \\ I.E.S. León Felipe (Torrejón de Ardoz)
}

RESUMEN: . Durante el Sexenio democrático se popularizó en la prensa, la oratoria parlamentaria y la literatura la identificación de España con la «Polonia del Mediodía». Este tópico retórico reflejaba el pesimismo provocado en todos los partidos por la inestabilidad política, la intervención de las potencias en los asuntos internos españoles y la amenaza que pesaba sobre la integridad territorial. La idea de que España estaba condenada a un destino semejante al de Polonia alcanzó su punto culminante tras la proclamación de la república en 1873, cuando los gobiernos de Madrid luchaban en tres frentes a la vez: la guerra de Cuba, la guerra carlista y el levantamiento cantonal. Un análisis de los Episodios nacionales de Pérez Galdós permite seguir la evolución del tópico y analizar su influencia sobre la imagen de España, así como la buella que dejaría cuatro décadas después en el arranque de los movimientos separatistas, $y$ en especial en el nacionalismo vasco.

PALABRAS ClaVE: Historia contemporánea. Sexenio democrático. Historia de Polonia. Nacionalismo español. Nacionalismo vasco y catalán. Literatura española. Emilio Castelar. Benito Pérez Galdós. Sabino Arana.

ABSTRACT: During the Spanish democratic period of 1868-1874 it became popular in the press, parliamentary rbetoric, and literature to identify Spain as «the Poland of the South». This rhetorical expression reflected the pessimism provoked in all parties by the political instability, the intervention of foreign powers in Spanish internal affairs, and the menace posed to the territorial integrity of the nation. The idea that Spain was condemned to a destiny similar to Poland's reaches its climax after the proclamation of the Republic in 1873, when the governments of Madrid were fighting on three fronts: the Cuban war, the Carlist war, and the Cantonalist insurrection. An analysis of the Episodios nacionales of Pérez Galdós makes it possible to trace the evolution of this topic and its in-

Hispania, LXII/1, núm. 210 (2002) 167-220 
fluence over the national image of Spain, and the mark it left four decades later with the beginning of the separatists movements, especially Basque nationalism.

KEY WORDS: Contemporary history. Democratic Sexenio. History of Poland. Spanish nationalism. Basque and Catalonian nationalism. Spanish literature. Emilio Castelar. Benito Pérez Galdós. Sabino Arana.

Este artículo pretende aproximarse a la imagen de Polonia que tenían los españoles del último tercio del siglo XIX. A primera vista, parece objetivo difícil y, lo que es peor, baladí: el espacio que ocupaba en el imaginario colectivo una nación lejana, carente de Estado propio, resulta insignificante, tal como cabía esperar, si se mide con el mismo patrón que se aplica a otras más próximas en la geografía y en la historia, como Portugal (por no hablar de las que vivían además un momento cenital, como la Francia de la III República). En comparación, el material que se refiere a Polonia es extremadamente raro: ¿qué utilidad puede tener para el historiador? A nuestro juicio, existía una estrecha relación entre la imagen de Polonia que tenían los españoles y la que se formaban de su propia nación. El seguimiento de un tópico polaco de moda durante el Sexenio democrático puede aportar algunas claves sobre el desarrollo del nacionalismo español, y quizás contribuya también a explicar ciertas peculiaridades de los nacionalismos separatistas finiseculares.

\section{¿EN EL MAR NEGRO?}

Desde los tiempos en que Calderón situara la acción de su drama más universal en una Varsovia más irreal que la Andalucía de Potocki, Polonia había sido en España paradigma de país remoto y desconocido. A lo largo del siglo XIX, las noticias procedentes de allí habían llegado amortiguadas hasta la opinión pública española. Sólo los levantamientos de 1830 y 1863 rompieron el muro de silencio. En ambas ocasiones los liberales españoles se sintieron conmocionados por la suerte de una nación cuyo nombre solía ir acompañado de epítetos como «noble» y «mártir». Un Himno a Polonia escrito en 1863 versificaba estos tópicos:

$$
\begin{aligned}
& \text { iOb Polonia infeliz! Tierra oprimida } \\
& \text { por el yugo ominoso de un tirano, } \\
& \text { levanta ya la frente envilecida } \\
& \text { y empuñe el bierro tu cansada mano. }
\end{aligned}
$$

Polonia era una referencia para los españoles: lo era para los liberales, y también, por otras causas, para los ultramontanos; sin duda, una referencia negativa: aunque los polacos inspiraban simpatía, la falta de un Estado en ple- 
na era de los nacionalismos se consideraba una catástrofe poco menos que insuperable. Las expresiones de apoyo a la causa polaca solían acompañarse de reproches a los «verdugos». Quizás esa sea la razón de un curioso rasgo del liberal español: la animadversión por Rusia, difícil de explicar por la geografía, de ilógica intensidad atendiendo sólo a la historia. Para liberar a Polonia, el poeta llegaba a clamar por la intervención española:

\author{
Y tú, Patria invencible de Pelayo, \\ del entusiasta y bélico ardimiento \\ vuela, vuela al momento, \\ y lánzate a la Rusia como un rayo...
}

... claro que tanta simpatía no bastaba para inducirle a mirar el mapa. Si Calderón se tomó la licencia de hacer de Varsovia puerto de mar, nuestro vate invertía la dirección de su río, trasladando su desembocadura a lejanas orillas:

\author{
El Vistula, que raudo precipita \\ al Mar Negro su férvida corriente, \\ el grito patriótico repita \\ del ancho mundo a la asombrada gente.
}

Y lo peor no es el disparate, sino el hecho de que nadie lo advirtiese en los doce años que mediaron entre su primera publicación y la edición de $1875^{1}$. Pero es que esas solían ser las circunstancias que acompañaban las referencias a Polonia: simpatía, compasión, desconocimiento. Sin embargo, durante un período concreto de la historia española, en torno a los años críticos de 1872 1874 , aumentaron significativamente las alusiones a la historia y a la actualidad de Polonia. A lo largo de la década se publicaron algunos libros que alimentaban la famélica bibliografía española sobre esa nación ${ }^{2}$. Entre tanto, los

En las notas se utilizan las siguientes abreviaturas: $R d E$ (Revista de España), LR (La regeneración), LC (La cruz); las crónicas de la primera se abrevian así: Rpi (revista de política interior) y Rpe (revista de política exterior). E.N. vale por «Episodio nacional».

1 «Himno a Polonia», seguido de «Al glorioso levantamiento de Polonia en 1863 (con motivo de la actitud de la Europa)", en VeliLla Y RoDríGuez, José: Meditaciones y Recuerdos. Poesía, Sevilla 1875, pág. 3 y ss. La Revista de España (en adelante, $R d E$ ), tomo XLVIII (1.-2. 1876), pág. 544, señala que este himno, el más conocido del autor, se inspira en la Oda al dos de Mayo de Nicasio Gallego.

2 En 1874 apareció uno de los raros libros que trataban de las relaciones hispano-polacas: $M i$ sión secreta del embajador D. Pedro Ronquillo en Polonia (1674), del historiador Antonio Rodríguez Villa. Poco después, la Institución Libre de Enseñanza organizaba una conferencia en el Ateneo madrileño sobre La moderna literatura polaca y José Ignacio Kraszewski (José Leonard). Vid. Revista de España , tomo XLII, (1.-2. 1875), pág. 139. Esta conferencia se publicará en RdE, tomo LXIV, (9.10. 1878), y también como folleto. En la década siguiente se editaron al menos dos traducciones de novelas: Ulana (Novela original de José Ignacio Kraszewski, traducida del polaco por Francisco de Mas y Otzet, Madrid 1885; traducción catalana en 1903), y Tadeo Soplica o el último proceso en Litua- 
periódicos prestaban mayor atención al presente polaco: algunos nombres, incluso algunos rostros, como el del Arzobispo de Posen, empezaban a resultar familiares a los lectores. Y, lo que resulta más importante, tanto la oratoria política como la sagrada abundaban en alusiones a Polonia, a su martirio y a su suerte aciaga. Esta vez, ningún suceso polaco de primera magnitud justificaba esa atención. En realidad, el súbito interés tenía más que ver con los acontecimientos de aquí que con los de allá: pues tanto la imagen liberal de la nación heroica de Kosciusko, traicionada por los poderosos, como el icono del pueblo católico, oprimido por gobernantes impíos, evocaban en un momento crucial de la evolución del nacionalismo español los peligros a que amenazaban a España. En aquellos años, españoles de todos los partidos temieron que su patria se convirtiera en la Polonia del Mediodía.

\section{POLONIA EN EL IMAGINARIO ESPAÑOL}

Podemos explorar la imagen de Polonia en la opinión pública española del siglo XIX orientándonos con ayuda de tres coordenadas. Por supuesto, no todas tenían el mismo interés en todo momento, ni era igualmente válidas para todas las opciones ideológicas; pero su combinación permite localizar con bastante aproximación el lugar que correspondía a esta nación en el imaginario colectivo. La primera nos sitúa sobre el que podríamos llamar «eje histórico»: un ámbito en el que primaban las relaciones internacionales y los condicionantes geográficos. Polonia no se encontraba entre las naciones con las cuales España había mantenido relaciones más estrechas. Los contactos diplomáticos habían sido relativamente escasos, y ni la geografía ni la economía contribuían a mejorar el conocimiento mutuo. Sin embargo, sí existía conciencia de paralelismos históricos evidentes: el pasado de ambas era más glorioso que su presente, y las dos habían sido durante siglos frontera de la Cristiandad: la hazaña de Sobieski se comparaba tradicionalmente con la Reconquista o con Lepanto. Sin embargo, para nosotros resulta más importante la relación establecida entre la guerra de la Independencia y la lucha nacional de los polacos, en especial con ocasión del levantamiento de 1863: En España, la nación hidalga por excelencia, la causa de Polonia ba inspirado quizá un sentimiento de interés más general que en ninguna otra nación de Europa $\{\ldots$... ¿No existe cierta afinidad entre la revolución polaca de 1863 y la revolución española de 1808?... ¿Cómo los descendientes de los héroes del 2 de mayo habian de dejar de simpatizar con los valientes bijos de Kosciusko? Es imposible que no se quieran dos naciones que ban pasado por pruebas análogas y que ban empuñado las armas en épocas aciagas impulsadas por un mismo sentimiento ${ }^{3}$. Anote-

nia: narración bistórica. (de Adam Mickiewicz, primera traducción española por León Medina, Madrid 1885.).

3 AlBert De Álvarez, Joaquín: Revolución de Polonia en 1863: historia de los heroicos esfuerzos bechos por los bijos de aquel infortunado pueblo para reconquistar su libertad e independencia: Barcelona

Hispania, LXII/1, núm. 210 (2002) 167-220 
mos de paso una paradoja: la lejanía y el desconocimiento recíproco favorecían que los paralelismos - construidos a partir de una visión distante, de carácter esquemático y simplificador- desemboçaran en una identificación simbólica, siempre que se dieran ciertas condiciones; probablemente, esto no habría sido posible de tratarse de pueblos más próximos y mejor informados. Las condiciones propicias - es lo que esperamos demostrar - se dieron durante el Sexenio.

Mucho más cercana a España era la situación de Polonia en el segundo eje de coordenadas: el religioso. Este factor conservaba una importancia mayor de la que hoy suele concederse, dada la tendencia a olvidar que la época de Darwin y Marx, de El origen de las especies. y El capital, fue también la de Pío IX y el Syllabus. En los años posteriores a la brecha de Porta Pía la cuestión romana determinaba la Weltanschaunng de los católicos. La guerra franco-prusiana se veía como una lucha religiosa - revancha de Westfalia - que había supuesto la derrota del catolicismo y la fundación del primer imperio protestante. Bismarck, gran adversario del papa, era también enemigo acérrimo de la causa polaca. Para los ultramontanos españoles, cuya importancia política e ideológica es difícil sobrestimar, el polaco era un pueblo católico perseguido por cismáticos y luteranos. Por otro lado, a la identidad confesional el clero polaco añadía la tendencia ultramontana, matiz decisivo después del primer concilio Vaticano.

Por último, para entender a los europeos del XIX resulta imprescindible tener en cuenta un factor que hoy llamaríamos cultural o etnográfico, pero que entonces se calificaba con un adjetivo que se presta a equívocos desagradables: racial. Por supuesto, en el período al que nos referimos, más de veinte años antes del affaire Dreyfus, el significado de «raza» era muy diferente del que llegaría a tener en el siglo XX. En esta que bien podríamos llamar «la edad de la inocencia» del racismo, la raza no sólo era un concepto común: además era progresista, o al menos anticlerical, y atraía especialmente a republicanos y demócratas. Era obvio que los polacos eslavos y los españoles latinos pertenecían a «razas» distintas. Pero, si su raza les separaban, les aproximaba una posición análoga dentro de sus respectivas «familias», y dos fases aparentemente consecutivas en el desarrollo de lo que entonces se consideraba el ciclo vital de

1863, pág. 53. Del lado polaco se apreciaban también esas coincidencias, como demuestra el $\mathrm{Pa}$ rallèle historique entre l'Espagne et la Pologne aux XVIe, XVIIe et XVIIIe siècles de Joachim Lelewel (París, 1835). Vid. KIENIEWICZ, Jan: «La obra de Joachim Lelewel, "Paralelo histórico entre España y Polonia en los siglos XVI, XVII, XVIII (1831)"”, en Hispania, LI/178 (1991), págs. 695-734. Sobre el tema complementario del que aquí tratamos, la visión de España en Polonia, Vid. KIENIEWICZ, Jan: «Dantisco: diálogo y futuro de las relaciones hispano-polacas», Acta Universitatis Wratislaviensis $\mathrm{N}^{\circ} 1875$, Estudios Hispánicos VI, Wroclaw, 1997) y «Confines y fronteras. El paralelo histórico a finales del siglo XX» ( en BLANCO PICADO, A.I., y EMINOwICZ, T. (ed.): Europa del Centro y del Este y el Mundo Hispánico. Simposio internacional de hispanistas. Cracovia, 1996). Un análisis del papel desempañado por España en la mitología nacional polaca en KIENIEWICZ, J.: «L'Espagne comme un modèle positif et négatif des Polonais au XIX siècle: continuité et discontinuité dans la mythologie nationale polonaise» (Acta Poloniae Historica, $\mathrm{n}^{\circ} 58,1988$ ). 
los pueblos. En el momento en el que la caída del II Imperio parecía señalar el declive latino y el ascenso germano, España pasaba por ser un ejemplo acelerado de decadencia, como lo había sido Polonia un siglo antes dentro de la familia eslava. En los arranques del darwinismo social (The Descend of Man se publicó en 1871), la idea de que las naciones combatían entre sí por su subsistencia, movidas por instintos de agresividad racial - aplicación a la historia del concepto biológico del struggle for life-, gozaba de aceptación casi general: Cuando entre los irracionales suplanta una raza superior a otra inferior, mediante la lucha, y el ordinario exterminio de la que queda vencida, progresa la escala zoológica (...) Hasta entre los racionales mismos se ba visto desaparecer completamente a los vencidos, no ya sólo aniquilados, sino aún devorados por sus vencedores, afirmaba tajantemente el católico Cánovas en noviembre de $1870^{4}$, todavía bajo la tremenda impresión causada por los acontecimientos de septiembre; y la última frase, sin dejar de ser una advertencia a los españoles, encerraba una alusión inequívoca a la tragedia polaca. Si Francia, "vanguardia de la raza latina», se sentía insegura ante su futuro tras la amputación de Alsacia-Lorena, equé podía esperar España, pobre, atrasada e inestable, agitada por la revolución y asolada por la guerra civil? Tan generalizada estaba entonces la creencia en su irremediable decadencia, tan aceptada la idea fatalista de que las naciones estaban sujetas ciclos inexorables, que mientras los españoles temían ser la «Polonia del Mediodía», el estado mayor prusiano, eufórico por la victoria, soñaba con que Francia sería pronto una «segunda España»s.

Para los observadores del siglo XIX, resultaba evidente que la España de 1872 se parecía mucho a la Polonia de 1772. Cuando ejercía la hegemonía en la marca oriental de Europa, Polonia tuteló la infancia de las potencias que habrían de acabar con ella. Los reyes polacos concedieron un título real a sus vasallos, los marqueses de Brandenburgo; los dominios polacos llegaban al mar Negro cuando el señor de Moscú era un régulo oriental; en 1683 un polaco salvó la capital de los Habsburgo de la suerte de Constantinopla. Sólo una decadencia biológica o una degeneración moral podía explicar que un siglo después pereciese desmembrada, minada por los vicios de la monarquía electiva y víctima del egoísmo de sus notables, siempre dispuestos a solicitar ayuda ex-

${ }^{4}$ Cánovas del Castillo, Antonio: Discurso pronunciado por el Excmo. Sr. D. ... el día 26 de noviembre de 1870 en el Ateneo científico y literario de Madrid con motivo de la apertura de sus cátedras», Madrid 1870. Págs. 37-38.

5 RuBIO, Javier: España y la guerra de 1870, Madrid 1989, tomo II, pág. 679, n. 143. Rubio resume así la visión europea: España era, a comienzos del siglo XIX, una desgraciada e incorregible nación que producía no poco asombro, y alguna compasión, por su inestabilidad, por su turbulencia, por su incapacidad para resolver los problemas de gobierno. En los últimos años del reinado de Isabel II (...) el sentimiento que España despertaba predominantemente parecía ser el de compasión. España (...) se dirigía, desde mucho antes de dicho reinado, irremediablemente hacia su decadencia y su descomposición (pág. 678). Es el complemento perfecto del tópico polaco: mientras eran objeto de la compasión de pueblos más felices, los españoles compadecían a los polacos. 
tranjera para solventar sus diferencias. También aquí se achacaban los males de España a la división interna, a la incapacidad de los partidos para sacrificar los intereses de su facción al bien común; también aquí se temía la intervención extranjera. La búsqueda de un candidato para el trono español recordaba las intrigas que habían sentado a un sajón sobre el polaco, comienzo de su rápida decadencia. En muchos aspectos, los españoles de 1872 se sentían tan humillados como los polacos de 1772: tras dominar Italia durante siglos, tendrían ahora por rey al vástago de una casa ducal despreciada por la aristocracia hispana; después de haber sido por largo tiempo una potencia de primer orden, veían que ahora otras naciones intervenían con descaro en sus asuntos internos, lanzaban vetos y amenazaban con "poner orden». Aquellas ex-colonias inglesas que un día se emanciparan con ayuda de Carlos III pretendían ahora arrebatar a España, descubridora y conquistadora de las Américas, los últimos jirones del que un día fuera el mayor de los imperios. Lejanos, olvidados los esplendores de antaño, los españoles del siglo XIX se sentían atrasados e ignorantes respecto a las «naciones cultas». A finales del siglo XVIII los poderosos pronunciaron una terrible sentencia: Finis Poloniae ¿Había llegado el momento del Finis Hispaniae? En esta crucial encrucijada, en esta hora decisiva de la evolución del nacionalismo español, un espectro recorría la Península: era el fantasma de los repartos de Polonia.

\section{POLONIA EN ZARAGOZA}

Para alcanzar nuestro objetivo hemos escogido un modesto punto de partida: una simple alusión a los repartos de Polonia que figura en un libro que se publicó en el último año del Sexenio:

Lo que no ha pasado ni pasará es la idea de nacionalidad que España defendía contra el derecho de conquista y la usurpación. Cuando otros pueblos sucumbían, ella mantiene su derecho, lo defiende, y sacrificando su propia sangre y vida, lo consagra, como consagraban los mártires en el circo la idea cristiana. El resultado es que España, despreciada injustamente en el Congreso de Viená, desacreditada con razón por sus continuas guerras civiles, sus malos gobiernos, su desorden, sus bancarrotas más o menos declaradas, sus inmorales partidos, sus extravagancias, sus toros y sus pronunciamientos, no ba visto nunca, después de 1808, puesta en duda la continuación de su nacionalidad; y aún boy mismo, cuando parece hemos llegado al último grado de envilecimiento, con más motivos que Polonia para ser repartida, nadie se atreve a intentar la conquista de esta casa de locos.

Hombres de poco seso, o sin ninguno en ocasiones, los españoles darán mil caídas, boy como siempre, tropezando y levantándose, en la lucha de sus vicios ingénitos, de las cualidades eminentes que aún conservan y de las que adquieren lentamente con las ideas que les envía la Europa central. Grandes subidas y bajadas, grandes asombros y sorpresas, 
aparentes muertes y resurrecciones prodigiosas reserva la Providencia a esta gente, porque su destino es poder vivir en la agitación como la salamandra en el fuego; pero su permanencia nacional está y estará siempre asegurada ${ }^{6}$.

Zaragoza era el sexto Episodio nacional de Pérez Galdós. En la época que nos ocupa, la fama de la gesta de 1808-1809 había traspasado las fronteras, consagrada como paradigma heroico. Un italiano que viajaba por España en 1871, ansioso de encontrar las buellas de esa lucha de Titanes que aterró al mundo, entraba en la ciudad dominado por un sentimiento de tímido respeto. La fama terrible de Zaragoza me imponía y casi me remordía la conciencia de haber profanado su nombre tantas veces en la clase de Retórica, arrojándolo al rostro de los tiranos como un guante de desafío(...). Al doblar una esquina, me pareció ver lucir en las ventanas fusiles y puñales, y como si oyera lejanos gritos de beridos. En aquel momento no sé lo que bubiera dado por ver salir el sol; tal era el ansia que me devoraba de visitar una a una aquellas calles, aquellas plazas, aquellas casas que bicieron célebres las lucbas desesperadas y borribles matanzas, que inspiraban a tantos pintores, que ban sido cantadas por tantos poetas y que tantas veces soñe en Italia...7.

Este libro fue uno de los primeros triunfos literarios de Galdós: todavía hoy suele considerarse el episodio más logrado de la primera serie. Su esperada aparición se hizo coincidir con el Dos de Mayo de 1874, celebración reducida hoy a la modesta condición de festividad autonómica, pero que entonces destacaba por su patriótica solemnidad. Nuestro viajero se admiraba de la dignidad, el amor y la veneración con la que los españoles festejaban el 2 de mayo, una celebración que honra no sólo al pueblo español sino también al corazón bumano. Es la verdadera fiesta nacional de España, el solo día del año en que se olvidan los rencores políticos y todos los corazones se unen en un sentimiento común ${ }^{8}$. Y esta admiración nos admira a nosotros, pues no debía ser fácil de impresionar con celebraciones patrióticas un italiano que había vivido unos meses antes la culminación de la unidad de su patria.

El éxito fue perdurable. Se hizo una adaptación infantil de los Episodios de la guerra de la Independencia ${ }^{9}$; durante un siglo largo se incluyeron fragmentos del relato en los libros escolares, e incluso ha aparecido una reproducción de un

\footnotetext{
${ }^{6}$ PÉrez Galdós, Benito: Zaragoza (E.N. nº), Madrid 1992 [1ª ed.: 1874], cap. XXX, pág. 212. Los subrayados son nuestros.

7 AMICIS, Edmundo de: España. Impresiones de un viaje hecho durante el reinado de Don Amadeo I. Barcelona, 1899, pág. 37. Cierto complejo de culpa que provoca en su ánimo Zaragoza —miré fijamente al camarero que me conducía a mi cuarto, sonriéndole amistosamente, como diciendo: 'no bay cuidado, no soy un invasor' - tiene que ver sin duda con su nacionalidad, ya que el autor era consciente de la división de los españoles a propósito del rey. En esta época era tópica entre carlistas y republicanos una -injustísima - equiparación de Amadeo con José Bonaparte de la que aún quedan vestigios en manuales y libros de texto. Habría que indagar acerca de la escasa fortuna historiográfica de personajes como Prim o Amadeo, reducidos a un inmerecido olvido o semiolvido que se refleja incluso en el callejero: es posible que el tópico polaco tenga algo que ver con esa deplorable amnesia.

8 Ibidem, pág. 166:

9 La editorial Hernando publicó en 1908 y 1917 un extracto de los Episodios de la guerra de la Independencia para uso de los niños; hay una versión narrada por su bija de 1948.
} 
párrafo del manuscrito en los billetes de banco. Junto con las obras de Goya, podemos decir que la primera serie de los Episodios ha sido un elemento clave en la configuración de la imagen nacional de España en los últimos ciento veinticinco años. Lo que explica por qué hoy, en plena fase de repliegue del nacionalismo español, ha perdido tanta popularidad.

Evidentemente, los repartos polacos no guardan relación alguna con el argumento de Zaragoza. Conviene advertir además que la alusión a Polonia no sólo se refiere a la época en que transcurre la narración (1809), sino que se proyecta sobre el presente (1874) hasta el futuro, ya que el elemento de comparación que sirve para subrayar la permanencia de la idea de la nacionalidad de España son los «efímeros» Imperios franceses: el primero, aquella tempestad que conturbó los primeros años del siglo, y que pasó como pasan las tempestades; el segundo, que también pasó, derribado (...) por su propia soberbia, y aún un hipotético tercero que no dará sombra al mundo durante siglos, y apenas servirá para que algunos hombres se calienten con el fuego de su última leña ${ }^{10}$. Parece que la alusión a Polonia es una frase hecha, un giro coloquial incluido más por descuido que por reflexión. ¿Qué motivos justificaban la desmembración de Polonia? Probablemente, si se hubiera parado a pensarlo, Galdós no habría expresado esa temeraria afirmación sobre una nación por la que los liberales españoles sentían una simpatía profunda. No cabe duda de que él compartía la opinión general favorable a Polonia: en su obra periodística se encuentran referencias perfectamente tópicas a la 'nación desventurada', cuya suerte ha impresionado siempre a todas las almas generosas ${ }^{11}$. Pero es que Zaragoza no es un sesudo ensayo político, ni un documentado análisis histórico, sino una novela emocionante. El fragmento que analizamos pertenece además a su parte más subjetiva: el capítulo comienza con una invocación -Vete lejos de mí, horrible pesadilla-, como si el narrador advirtiera el ascenso de fuerzas profundas, innominadas, que se enseñorean de su voz. En este pasaje no habla solamente Gabriel: es como si Galdós, embargado por el sentimiento, hubiera acertado a expresar una oscura impresión grabada en lo profundo de la psique de los españoles. Éste parece ser uno de esos casos en que el historiador aprende más del descuido, del detalle subliminal, que del discurso deliberado y de su justificación. Mientras que toda la voluntad de Galdós se orienta a exaltar el heroísmo de los zaragozanos, introduce con toda naturalidad una extraña comparación entre los destinos de España y de Polonia que revela hasta que punto cierto tópico estaba profundamente arraigado en la mente de los españoles. Un tópico quizás antiguo, pero que en aquel momento había cobrado súbita actualidad y un nuevo significado.

10 Zaragoza, cap. XXX, pág. 209. En efecto, tras el fracaso del legitimismo francés en octubre de 1873 , el bonapartismo parecía una salida para lo que aún se consideraba un período de interinidad republicana.

11 PÉREZ GALdós, Benito: "Organización actual del Imperio austríaco», RdE, tomo XVI (Madrid, 9.-10. 1871), pág. 509 y ss. Es un comentario del libro de Laveleye: Austria y Prusia después de Sadowa. 
Aunque rastrear el origen de la expresión Polonia del Mediodía excede los objetivos y los límites de este artículo, podemos formular una hipótesis sobre su procedencia y significado primitivo. El tópico aparece siempre relacionado con la guerra de la Independencia: en esa época, el recuerdo de la desaparición de Polonia estaba fres $\mathrm{CO}^{12}$, aunque en realidad - y eso es algo que parece haberse olvidado posteriormente- originariamente el tópico tenía más que ver con Tilsit —el «cuarto reparto de Polonia»— que con los anteriores. Es posible que procediera de Francia: nos parece muy probable que en un primer momento se refiriera tan sólo a Portugal — repartido en Fontainebleau al mismo tiempo que se defraudaba a los polacos en Tilsit-, aunque más tarde su aplicación se extendió a toda la Península. Las memorias de Godoy, publicadas a partir de 1836, contenían las célebres "Especies y cuestiones proponibles» comunicadas en febrero de 1808 a Carlos IV: Napoleón, conquistada esta paz de nuevo en los campos de Polonia, se sentía con derecho para emplear toda suerte de medios, ordinarios o extraordinarios, regulares 0 irregulares, violentos o suaves en todo el continente. El segundo punto decía textualmente: Que zanjados y asegurados los designios de Su Majestad Imperial y Real en el norte de Europa por los Tratados de Tilsit t...) faltaba a Su Majestad realizar las mismas intenciones por entero en los pueblos el Mediodía. El emperador, que en los años anteriores ya había propuesto en varias ocasiones la cesión o permuta de algunas partes del territorio de su aliado español (la entrega de Pasajes a Francia o la de las Baleares a los Borbones napolitanos; el trueque de las regiones de más allá del Ebro por el centro de Portugal), hablaba sin rebozo de la constitución de una «Marca Hispánica», es decir, de la anexión al Imperio de las provincias «transiberinas», o al menos de la constitución de una "potencia neutra» entre los Pirineos y el Ebro. Nos vendrá bien recordar un detalle cuando analicemos la utilización del tópico en 1873: la excusa que justificaba tamaña pretensión era la existencia de un parti-

${ }^{12}$ Cada vez que se aludía a la tragedia polaca, los autores españoles solían subrayar que España fue la única monarquía europea que protestó formalmente ante las potencias concertadas. España simpatiza con la causa de los polacos, como ha simpatizado siempre con todas las grandes causas. Sí, nosotros que pisamos esta tierra cubierta con las cenizas de tantos béroes, y respiramos este aire que ba llevado al seno de Dios el alma de tantos mártires (...) nosotros fuimos los únicos que protestamos contra el repartimiento de Polonia cuando Francia estuvo muda e indiferente Inglaterra, y muerta Italia; nosotros, que nos gloriamos de baber enseñado a los pueblos modernos en las páginas de la guerra de la Independencia a vencer a los conquistadores, debemos trabajar por Polonia en cumplimiento de nuestros destinos históricos...(Albert de Álvarez (1863), op.cit., pág. XIV). El artículo de Borso (vid. nota 64) se refiere también a la «hidalguía» de Carlos III (RdE, tomo XXI, pág. 333); Leonard afirmaba (cfr. nota 4): A fines del siglo pasado... Polonia desapareció del mapa ante la indiferencia de toda Europa, excepto España y Turquía, cuyos embajadores protestaron solemnemente ( $R d E$, tomo LXIV, 9.-10. 1878, pág. 522). Como siempre, el más elocuente es Castelar, que anuncia que si hubiera 'un Josafat de las naciones', España se presentaría ante el tribunal aduciendo en su defensa, entre otras cosas, protestas como la escrita contra la desmembración de Polonia (CASTELAR, Emilio: Un año en París. Madrid, 1875, pág. 166). Se ha notado también un cambio de actitud e intensidad en las relaciones hispano-polacas en el siglo XVIII, especialmente durante los reinados de Carlos III y Carlos IV. Vid. KIENIEWICZ (1997), op.cit., págs. 33 y 34

Hispania, LXII/1, núm. 210 (2002) 167-220 
do de «anarquistas» (sic) en la Corte española que podía provocar con sus acciones un torbellino: la existencia, en fin, de España como nación independiente, no podría menos de correr en tal revuelta un gran peligro ${ }^{13}$. El propio Godoy reconoce lo cerca que se estuvo de admitir la brutal imposición: en una misiva -interceptada por una oportuna contraorden a punto de cruzar el Ebro- el Príncipe de la Paz, por orden de Carlos IV, ofrecía a Napoleón la constitución de un virreinato «independiente y neutro» en Vizcaya y Navarra a favor del rey de Etruria o de algún infante de Castilla. Invocando el testimonio de Escoiquiz, Godoy afirmaba que, camino de Bayona, Fernando y su camarilla contemplaban sin rubor la posibilidad de salir del paso con la cesión de las regiones del Ebro. Desde luego, un fuerte vínculo une el tópico polaco con este río y con la capital aragonesa: $\mathrm{Na}$ poleón ennoblecía su ambición comparándola nada menos que con la expedición de Carlomagno a Zaragoza (aunque olvidaba, recuerda oportunamente Godoy, la rota de Roncesvalles). El emperador no renunció a su marca hispánica ni siquiera después de haber sentado a José en el trono de España: el decreto del 8 de febrero de 1810 creaba cuatro gobiernos militares en Cataluña, Aragón, Navarra y Vizcaya, lo que de hecho suponía su anexión a Francia. En las negociaciones entabladas por orden de José con objeto de salvaguardar la integridad territorial que había jurado mantener, aumentaron aún más las peticiones francesas: reclamaban, entre otros territorios, la ciudad de Zaragoza, pese a levantarse sobre la orilla derecha, y ofrecían a cambio - como ya se ofreciera antes a Carlos IV - la cesión de una parte de Portugal. El proyecto de desmembración de la «Polonia meridional» no se abandonó del todo mientras hubo posibilidad de victoria: de hecho, el 14 de enero de 1812 una orden dividió Cataluña en cuatro departamentos, aplicando allí la estructura administrativa francesa.

\section{LA SOMBRA DE UN CENTENARIO}

Para proseguir nuestro relato debemos saltar hasta el verano de 1872. En Europa todavía resuena el eco de los fusilamientos que han teñido de rojo una tapia del Pére Lachaise. Francia sufre la resaca de l'année terrible; en Alemania, la victoria está empañada por el temor a la revancha. Los católicos temen por la salud del octogenario Pío IX, 'prisionero' en el Vaticano. En España, la monarquía de Amadeo I está entrando en su crisis final. En abril, el pretendiente carlista ha lanzado un llamamiento para que sus partidarios se levanten al grito de «iabajo el rey extranjero!» (y dicen las malas lenguas que «extranjero» es palabra que don Carlos — nacido en Ljubiana, criado en Italia, residente en Austria y Francia - no es capaz de pronunciar correctamente). Para cruzar la frontera, Carlos VII ha escogido una fecha simbólica: el 2 de mayo. Muy pronto tendrá

13 Godoy, Manuel de: Memorias del Príncipe de la Paz, Madrid 1965, vol. II, págs. 271-277 y 286. 
que retirarse, pero su intervención ha inaugurado un conflicto que no concluirá hasta 1876. En este verano de 1872 se producen nuevos levantamientos de partidas carlistas en el Norte. También prosigue la guerra civil en Cuba: las acciones brutales de los «voluntarios» han concitado la oposición de una parte de la población que hasta el momento había sido neutral; la intervención de los EE.UU. parece cada vez más próxima. En Madrid los gobiernos se suceden en medio de escándalos; el ambiente político está enrarecido: en apenas dos años tendrán lugar tres elecciones generales y se sucederán seis gabinetes ministeriales. Alfonsinos, carlistas y republicanos han pactado para echar al saboyano. La victoria de los radicales de Ruiz Zorrilla en las elecciones de agosto de 1872 provoca la alarma del ala moderada del régimen. El rey no ha abdicado - le esperan aún los meses más críticos y desagradables de su reinado-, pero su situación empieza a ser insostenible. Justo en ese momento se anuncia que en septiembre tendrá lugar una conferencia de los tres Emperadores en Berlín.

La noticia es cuando menos sorprendente: parece imposible que Austria perdone a Prusia apenas seis años después de la humillación de 1866; o que Rusia y el Imperio Austro-Húngaro puedan entenderse, cuando el Zar acaba de denunciar el acuerdo de neutralización del mar Negro impuesto tras la guerra de Crimea. Desde el Ausgleich de 1867 los intereses magiares son cada vez más importantes en la monarquía dual de los Habsburgo, y esos intereses chocan con el paneslavismo ruso en los Balcanes. Sin embargo, la habilidad de Bismarck conseguirá lo imposible: los emperadores se reunirán, y al año siguiente formalizarán el embrión del primer sistema bismarckiano. Hoy podemos interpretar aquella maniobra como un intento de romper un peligroso aislamiento: la obsesión de Bismarck es evitar una guerra en dos frentes como la que estallará en 1914. Pero a los ojos de sus contemporáneos, al canciller le movían razones más siniestras. Entre los ultramontanos, la conferencia provoca una terrible alarma: en ese extraño congreso ven un fabuloso complot anticatólico contra los dos poderes supremos del catolicismo, el papa y Francia.

Sí, es cierto que en 1872 la fille aînée de l'Église ya es república: pero es una república «de orden», enemiga de los demagogos, represora de la Comuna, amargada por la derrota y tentada por la revancha, en la que se trabaja con ahínco para facilitar el advenimiento del nieto de Carlos X. El sueño ultramontano es que en Francia se restauren los borbones, que triunfe el carlismo en España, y que ambas ramas legítimas borren del mapa al reino de Italia y devuelvan su corona a Pío IX, siguiendo el precedente de la expedición francoespañola de 1849. No cabe esperar la colaboración de los Soberanos del Norte en tal empresa: engañados por Bismarck, han olvidado sus intereses naturales y los sagrados principios que sus antepasados juraron defender en 1815, y están decididos a impedir la restauración legítima en Francia y España, a sostener la usurpación de Roma, incluso a imponer un papa gibelino en el próximo cónclave.

Bismarck amenaza con utilizar el derecho de veto en el cónclave que tradicionalmente se atribuían el emperador y los reyes de Francia y España. Cual- 
quier maniobra parece posible con Roma ocupada por las tropas italianas, el Habsburgo aliado con el Hohenzollern, el trono español ocupado por un Saboya y Francia excluida por su condición de República. Para la prensa ultramontana, la mano del canciller maneja los hilos ocultos de la masonería y está detrás de todas las medidas anticatólicas. En Berlín no estará Víctor Manuel, pero es seguro que se hablará de Roma: Bismarck conseguirá que Austria perdone Solferino como ha perdonado Sadowa. España, y Portugal, donde reina como consorte una Saboya, forman sin duda parte de una estrategia global ${ }^{14}$. Pío IX puede morir en cualquier momento: en tal caso, ¿cuál sería la postura de un gobierno radical? ¿invocará Amadeo el derecho de veto del que gozaba tradicionalmente el «católico rey de España» para impedir la elección de un ultramontano? En el verano de 1872 una nota enviada a las potencias aumenta la tensión: Bismarck propone someter la elección papal al requisito de la aprobación de las potencias. ¿Está garantizada la libertad del cónclave en una ciudad en manos de las logias? ¿podrá tomar posesión del Vaticano un papa elegido fuera de Italia? El cardenal Hohenlohe, perteneciente a una familia bávara de tendencia josefista, lidera la oposición al partido ultramontano. En Alemania, una parte del clero y de los fieles se han separado de Roma: el cisma de los «viejos-católicos», ¿será, como anuncian eufóricos los protestantes, el comienzo de una segunda y definitiva Reforma? Bismarck habla de Canossa, pero todos piensan en Aviñón.

Es precisamente en este momento cuando la prensa empieza a recordar una efemérides centenaria. En 1772, la zarina Catalina, el rey Federico de Prusia y la emperatriz María Teresa se habían repartido un tercio del territorio polaco. En el primer centenario de aquel acuerdo, los sucesores de aquellos monarcas, más poderosos aún de lo que lo fueron sus antecesores, volvían a reunirse. Aquella conmemoración casi coincidía con otra no menos luctuosa para los ultramontanos: en 1773 acabó el proceso de extinción de la Compañía de Jesús. Una vieja cuestión volvía a debatirse: ¿fue válido el breve de supresión de la Compañía? Algunos afirmaban que Clemente XIV se había comprometido antes de su elección a acabar con los jesuitas a cambio del apoyo de los Borbones a su candidatura, lo que invalidaría su decisión por simoniaca. Pese a las apariencias, no se trata de un debate erudito sobre vetustas cuestiones de derecho canónico: lo que se pretende con el recuerdo del funesto precedente es advertir de lo que ocurrirá si el canciller consigue introducir sus manejos en el cónclave. La supresión de los jesuitas y el reparto de Polonia fueron, según los ultramontanos, los primeros pasos que llevaron a la Revolución. Las logias preparan una nueva ofensiva contra la Iglesia: ¿acaso no acaba Bismarck de expulsar a los jesuitas del Reich, iniciando una campaña de desprestigio de la Compañía similar a la que culminó en el Terror?

\footnotetext{
${ }^{14}$ Sobre las conjeturas que suscitó esta reunión, la posibilidad de una incorporación de Italia a la alianza, y las repercusiones de todo ello en España, vid. SALOM COSTA, Julio: España en la Europa de Bismarck, Madrid 1967, págs. 54-56.
} 
El diario madrileño La regeneración, uno de los más influyentes de la prensa carlista, será nuestro hilo conductor. En junio de 1872, las primeras noticias acerca de la campaña antijesuítica en Alemania coinciden con los rumores sobre las maniobras diplomáticas que Bismarck para asegurar la elección de un papa dócil a sus presiones. El 22 de junio comienza la publicación de El Gran Peligro ${ }^{15}$, un artículo por entregas que revela que la política antijesuítica en el Reich forma parte de una gran conjura para acabar con la Iglesia. Su argumento se basa sobre la comparación sistemática de los acontecimientos de 1872, de cuya responsabilidad se acusa a Bismarck como gran Maestre de la masonería, con los de un siglo antes, que supone planificados por Voltaire y realizados con el concurso del rey prusiano y la zarina. Aunque todavía no se hable de Polonia, la evocación de aquellos hechos implica referirse forzosamente a los protagonistas de aquel reparto.

En julio, un artículo titulado Berlín Roma Madrid continúa expresando la preocupación por las maniobras de Bismarck de cara al próximo cónclave; pero ahora, al peligro de la conjura anticatólica se añade el de la intervención extranjera - prusiana- en los asuntos españoles: Piénsese lo que se quiera, y mírese a cualquier parte, en todas veis el nombre de Prusia y a lo mejor se recuerda a Bismarck. Bismarck en Berlín; el acólito de Bismarck en Roma; los sectarios de Bismarck en Madrid. $Y$ es natural: como que ese es el gran negocio del mundo, la campaña emprendida bajo la conducta del generalísimo Bismarck contra la Iglesia católica ${ }^{16}$. El diabólico complot y la amenaza exterior -identificada con la pérdida de la soberanía o de la integridad territorial- confluyen a partir de agosto (momento en el que se cumple la efemérides del reparto), cuando a las noticias sobre el posible cónclave se añadan las del congreso imperial de Berlín: Recuerdo que en el siglo pasado se obraron en Europa dos grandes cosas: se expulsó a los jesuitas y se hizo a Polonia pedazos ${ }^{17}$. Arrecian las críticas contra los soberanos acusados de participar en la conjura: contra el zar, de quien se recuerda que hace tiempo oprime inicuamente a Polonia, y contra el káiser, que permite la persecución indigna contra los más valerosos campeones de la religión católica. Tampoco Francisco José se libra. Al fin y al cabo, aunque católicos, María Teresa y José arremetieron contra los jesuitas: lo pagaron caro, pero cien años después el católico emperador de Austria ha olvidado la lección, consiente que se ataque (...) a la Religión católica, y permite la aprobación de leyes contrarias a las enseñanzas de la Quanta Cura. Los Emperadores se presentan como defensores del orden y de la propiedad, enemigos de la Internacional y del comunismo, pero esos mismos monarcas han sorbido aquella propiedad de todo un pueblo que se llama Polonia. El recuerdo de la partición de Polonia llega también a la gacetilla, sección donde se publican coplas contra la

${ }^{15} L R, 22.6 .1872$ (sigue en 25.6., 27.6., 1.7., y 10.7.). El autor era Aparisi y Guijarro, director del diario y alma del partido carlista.

16 «Berlín, Roma, Madrid», Ibídem, 11.7.72.

17 «Persecución y emperadores», Ibídem, 27.8.72. 
dinastía saboyana: Para borracho un francés/ para mártir un polaco/ y para bacerse los sordos/ los señores saboyanos ${ }^{18}$.

El 2 de septiembre el diario anuncia que los polacos, siempre desgraciados, pero siempre fieles a su independencia, preparan una gran peregrinación hasta el santuario mariano de Censtocavia (sic) para el 8 de septiembre, fecha prevista del encuentro de los tres Emperadores. La víspera de la conferencia (que coincide con la conmemoración de la caída de Varsovia en 1831) se publica un alegato solemne dirigido a los monarcas, a los que se reprocha, junto a los males del presente, la vergüenza centenaria de aquellos repartos: iPobre Polonia! La sombra de Sobiesqui no pudo defenderla; rota fue en mil pedazos la espada de la cristiandad. Destrozamos a la beroica y mísera nación: aún está palpitando.... ${ }^{19}$. Al día siguiente, mezclados los comentarios políticos con la noticia del avance de una epidemia de cólera desde el este de Europa, se presenta este apocalíptico panorama: Se reúnen emperadores y reyes en Berlín, no sabemos para qué. Los internacionalistas van extendiéndose por toda Europa y toman posiciones. También toma posiciones el cólera morbo... Estado general de Europa: los emperadores charlando en Berlín; Víctor Manuel divirtiéndose en Roma; El Papa gimiendo en el Vaticano; el cólera y la Internacional por Europa, y cinco millones de soldados además de la Internacional y del cólera. Estado particular de España: disolución ${ }^{20}$. Nos llama la atención este texto: en él se ha dado ya el paso decisivo de identificar el problema de España con la «disolución». El recuerdo del reparto de Polonia ha llevado de forma natural a la idea del reparto de España. Rápidamente, la idea de que existe una conjura para perder al buen pueblo español, fiel a la Santa Sede a pesar de sus. gobiernos, se convierte en un tópico de la prensa carlista: Bismarck está en España; tiene ministros españoles que le secunden, diarios españoles que le sirven. Bismarck está combatiendo, $y$ nosotros, ¿qué bacemos?21. A partir del otoño, mientras en el congreso se discute una tímida ley de abolición de la esclavitud, la atención se dirige hacia Ultramar. La regeneración asume la dirección de la campaña antiabolicionista, utilizando como Leitmotiv una idea básica: la dinastía saboyana compromete la integridad nacional y puede costarle a España la pérdida de sus colonias, e incluso algo más. Las presiones de Washington provocan la indignación: se habla de humillación, de vergonzosos tratos y contubernios. No sólo peligra Cuba: se teme incluso por las Canarias; España comienza a ser la Polonia del Mediodía ${ }^{22}$.

La proclamación de la República fomenta las esperanzas carlistas: la carencia de reconocimiento internacional del gobierno de Madrid hace posible el reconocimiento de la beligerancia del pretendiente. Los liberales temen una internacionalización del conflicto del Norte, tal como ya ocurre en las Antillas. En verano se extiende el levantamiento cantonal. Los carlistas se burlan de

\footnotetext{
18 Ibídem 14.8.72.

19 Ibídem 2.9.72.

${ }^{20}$ Ibídem 3.9.72.

${ }^{21}$ Ibídem 16.7.72.

22 Ibídem 26.3.72. El subrayado es nuestro.
} 
Salmerón, elegido presidente el 18 de julio, llamando a su gabinete el gobierno alemán de Madrid ${ }^{23}$. Pero con esa expresión no sólo aluden a su krausismo, ridiculizado por los castizos como extravagancia germana; además, sugieren una connivencia con Bismarck, que ahora es, más que nunca, la bestia negra de los ultramontanos. En mayo de 1873 se han discutido en el Reichstag las Maigeset$z e$, la legislación anticatólica con que comienza la fase más dura del Kulturkampf. Ese mismo mes, en la fiesta del 2 de mayo, La regeneración compara a los patriotas de entonces con los que ahora solicitan la intervención extranjera: en 1808 sólo se oía una frase en toda la península: iViva España!; en 1873 por todas partes se oye esta otra: Intervención ${ }^{24}$.

El 20 de julio, agobiado por el aislamiento internacional de su gobierno, Salmerón lleva a cabo una acción desesperada: declara piratas a los barcos del cantón de Cartagena para que puedan ser apresados por cualquier potencia. Inmediatamente se produce un incidente: la fragata alemana Federico Carlos captura varios buques ${ }^{25}$. Esta vez, la conmoción alcanza a todos los partidos. ¿Será éste el comienzo de una intervención alemana en la Península? El descarado apoyo de la autoridades fronterizas francesas a los carlistas hace tiempo que produce malestar en Berlín: esta podría ser la excusa de una intervención para humillar a Francia antes de que pueda recuperarse de la derrota. ¿Qué papel reserva Bismarck a España en sus planes? El régimen republicano es débil: su hundimiento parece cuestión de tiempo. Pero, equé vendrá después de la República? Los carlistas exponen su utopía en un artículo titulado Tres estrellas en el borizonte ${ }^{26}$ : en Roma reinará Pío IX, Carlos VII en España y en Francia Enrique V. (faltan unos meses aún para que el affaire du drapeau blanc aleje definitivamente al conde de Chambord del trono de San Luis). Pero todavía hay que vencer un obstáculo: Bismarck. Si Prusia ha sido capaz de arrebatar Alsacia y Lorena a Francia, ¿qué no podrá hacer con España? La prensa es un hervidero de rumores: se dice que Alemania ambiciona las Filipinas, Puerto Rico, o poseer un enclave en el Norte, un Gibraltar prusiano en el Cantábrico ${ }^{27}$. O quizás pretenda algo más: un rey prusiano en Madrid. Efectivamente, en este momen-

23 Ibidem 24.7.73.

${ }^{24}$ Ibidem 2.5.73.

${ }^{25}$ La tragedia polaca está también presente en la campaña contra la intervención que emprende El cantón murciano, órgano del gobierno provisional de Cartagena: ...esa Inglaterra y esa Prusia, que se cruzan de brazos ante el incendio de ciudades, de mugeres y niños en la mártir Polonia, bajo el azote de la bárbara Rusia, esa Inglaterra y esa Prusia que no sienten remordimiento, que no sienten borror, que no tiemblan, que no palidecen, que no gimen ante esos crueles festines del ogro del Norte, mucho más crueles que el festín de Anteo en la mitología griega [y que, en cambio, ban intervenido en Cartagena]... La Prusia [que se asusta del cantón de Cartagena], ¿cómo no se asusta de baber tenido parte en el botín del antiguo reino polaco? ¿cómo no se asusta de baber disputado a la Rusia el sangriento ducado de Posen? (4.10. 1873). El día anterior ya se reprochaba a Prusia la anexión del ducado de Posen.

${ }^{26}$ Artículo de La Correspondencia de Ginebra, reproducido en $L R, 27.10 .73$.

27 Vid. AlVÁREZ GUTIÉRREZ, Luis: La diplomacia bismarckiana ante la cuestión cubana, 18681874. Madrid 1988 .

Hispania, LXII/1, núm. 210 (2002) 167-220 
to se plantea la segunda candidatura Hohenzollern ${ }^{28}$. ¿Lo consentiría Francia? ¿provocará la cuestión española otra guerra europea, como la que estalló en 1733 a causa de Polonia? ¿acaso no empezó de esa manera la ruina de aquel Estado?: No bay una sola nación de Europa que no se haya alarmado con la injerencia de Prusia en los asuntos de España, chocando a todos, y con razón, la forma especial con que presta sus servicios. Inglaterra ba lanzado sobre el Mediterráneo su poderosa escuadra de observación; Francia también; Austria se manifiesta preocupada, y lo mismo sucede a las demás potencias. ¿Qué se teme? ¿qué se maquina?... Hable el gobierno español, que debe saberlo. Hablen sus órganos, que la cuestión merece la pena, y hay españoles que con justicia se recelan de que su país pueda ser destrozado por la república de Salmerón (...) como lo fue la desgraciada Polonia ${ }^{29}$. Aquel mismo día, 5 de agosto, se conmemoraba el 101 aniversario de las conversaciones de San Petersburgo que sellaron el primer reparto.

\section{NACIONES MÁRTIRES}

El seguimiento del tópico polaco a través de La regeneración nos ha permitido mostrar que los españoles de entonces eran conscientes de las analogías entre el pasado de Polonia y el presente de España: desde esa perspectiva, lo que se comparaba con la España de Amadeo I o con la de Salmerón era la Polonia de Estanislao Poniatowski. Una ojeada a la prensa religiosa de la época nos permite detectar otra vuelta de tuerca en esta identificación entre ambos países: pues también el presente de Polonia podía servir para predecir el futuro de España.

La Cruz, revista religiosa de España y demás países católicos, es un excelente representante de la prensa religiosa que, digámoslo ya, no se limitaba precisamente a asuntos piadosos: la política y las relaciones internacionales ocupaban en ella un espacio considerable. Por otro lado, la repercusión de estas publicaciones dirigidas al clero no guardaba relación con la relativa modestia de sus tiradas: en un país en el que el analfabetismo afectaba a tres cuartas partes de la población, el púlpito era un medio privilegiado de propaganda. A través de La Cruz y de otras publicaciones semejantes se ha podido seguir con detalle los acontecimientos de 1872: la cuestión del cónclave y relación de este asunto con las alianzas tramadas por Bismarck fue tema casi monográfico de varios números; la política anticatólica de los gobiernos españoles es otro de los frentes abiertos. A partir de 1873, el Kulturkampf alemán ocupará un espacio creciente en la publicación. Las crónicas que ponían al clero español al corriente de las medidas antieclesiásticas del canciller transmitían un mensaje: la persecución

${ }^{28}$ Vid. ESPAdas Burgos, Manuel: Alfonso XII y los orígenes de la Restauración, Madrid 1990, pág. 17 y ss. ('La República española y el segundo intento prusiano') y' pág. 26 y ss. ('La nueva cuestión Hohenzollern en la República de Serrano').

29 «La intervención prusiana», $L R, 5.8 .73$. 
de los católicos en el Reich o en Suiza pronto sería copiada en España con la misma virulencia. La opresión de la 'mártir' Polonia era el modelo de todos los ataques contra la Iglesia: para La cruz, los ukases de Nicolás de Rusia contra los infelices polacos eran, junto a los edictos de Nerón y Domiciano contra los primitivos cristianos, la antonomasia de la legislación perseguidora y anticristiana ${ }^{30}$.

Consagrado como héroe de los ultramontanos desde que fuera perseguido por colocar al ducado de Posen bajo la protección del Sagrado Corazón (una devoción que recordaba aquí a los jesuitas y a los rebeldes de La Vendée), la figura del arzobispo Ledochowski se hizo familiar a los lectores españoles. En las crónicas acerca de los sucesos de Posen no se desatendían tampoco aspectos políticos que subyacían bajo el conflicto religioso: Hay más: una reciente disposición suprimiría en todos los establecimientos públicos la lengua polaca, que es la sola lengua del ducado de Possen, mientras el alemán, idioma que ha de sustituir al polaco, puede decirse es completamente desconocido. Como era deber suyo, el arzobispo envió una circular a los párrocos y maestros inculcándoles la obligación en que se ballaban de ensenar en la lengua polaca, que es la única al alcance de todos sus feligreses, y especialmente de los niños. Declara el digno prelado que, no llevado por sentimientos de nacionalidad, sino solamente por un sagrado deber de conciencia, había adoptado tal medida ${ }^{31}$.

A partir de enero de 1874, la supresión de la presa carlista dejaba a La cruz, protegida por su coartada religiosa, como el principal representante de esta tendencia ideológica. Justo entonces el conflicto religioso en Posen alcanzaba su máximo rigor. Toda la prensa se había hecho eco de la misiva dirigida por Pío IX al arzobispo, en septiembre de 1873, cómo publicaría al año siguiente el mensaje del obispo de Jaén (futuro arzobispo de Toledo), Monescillo, figura prominente de la Iglesia española: una carta en la que se evocaban recuerdos del concilio y en la que se expresaba la solidaridad del episcopado con sus hermanos polacos. Las noticias acerca de la prisión de Ledochowski se considera un acontecimiento doloroso, que merece ocupar la atención de los católicos de toda Europa. No tardarán, clama solemne $\mathrm{La}$ Cruz, en escribirse las actas de este nuevo mártir... del odio de los tiranos de Berlín ${ }^{32}$. Para entonces, no es sólo la prensa religiosa la que se ocupa de las noticias procedentes de Polonia occidental ${ }^{33}$. También se

${ }^{30} L C, 1873$, tomo I (1.-6.), pág. 467: se refiere a las Maigesetze. La conjura de Bismarck también ocupa un lugar considerable en publicaciones religiosas no carlistas. Por ejemplo, el semanario El consultor de los párrocos publica en la portada de siete de sus números a lo largo de 1872 artículos de política internacional relacionados con esta cuestión: Peligros para la Iglesia ("Alianza entre Italia y Alemania contra la Iglesia»), La diplomacia del futuro cónclave, Un notabilísimo documento de Pío IX («Peligros para la Santa Sede»), La fuerza de la Iglesia, La persecución de la Iglesia, La diplomacia de M. Bismarck y los fariseos, Se acerca la tempestad («Entrevista de los soberanos del Norte»). El consultor de los párrocos, números VII, VIII, IX, X, XIV, XV y XVII del año I (1872).

${ }^{31} L C, 1873$, tomo II (7.-12.), pág. 718.

32 Ibídem, 1874, tomo I (1.-6.), pág. 504.

33 El retrato de Ledochowski aparecía en portada de La ilustración española y americana de 15.4.74. Como ejemplo de la reacción de la prensa, podemos citar el artículo «El arzobispo de Posen", publicado en el alfonsino El tiempo el 26.3.73: a primera vista se presenta la cuestión religiosa; sin 
recordaba la brutal represión de los polacos sometidos al yugo de los zares en 1864. Diez años después, Pío IX seguía intercediendo por aquel pueblo ante la zarina que le visitaba en el Vaticano: Tengo un deber que cumplir, y me dirijo a vuestro elevado ánimo, a vuestro generoso corazón: es preciso que os bable de Polonia... ${ }^{34}$

\section{LA RESURRECCIÓN DE LA SANTA ALIANZA}

Hasta ahora nos hemos limitado a seguir la imagen de Polonia transmitida por la prensa carlista y ultramontana durante la crisis de 1872-74: hemos querido mostrar así la amplia difusión del tópico polaco y la repercusión que tuvo la conmemoración del centenario del primer reparto en su cristalización. Pero al mismo tiempo nos hemos alejado de nuestro primer objetivo, que no era otro que explicar cómo ese tópico llegó a Zaragoza. Aunque el Galdós de 1874 es mucho más conservador de lo que será en su vejez, no por ello comulga con los carlistas; es ante todo un liberal, y muy pronto Doña Perfecta (1876) le convertirá además en bestia negra de los 'neos'. No, el tópico polaco no ha llegado hasta él a través de esta vía: lo que ocurre es que en el lado opuesto del espectro político, liberales, demócratas y republicanos coincidían con los carlistas en desconfiar de la diplomacia bismarckiana. Ellos no pensaban en conjuras anticatólicas, sino en un intento de aislar a la República francesa e instalar en España un gobierno 'de orden'. En concreto, los republicanos españoles, ciegos ante los verdaderos intereses de la vecina república de monárquicos, seguían fieles a la patria de la Marsellesa. Muchos opinaban que Bismarck no había

embargo, en el fondo se descubre una constante persistencia por parte del gobierno prusiano de acabar con todo cuanto recuerde la existencia de la desventurada nación polaca. Hoy no queda de ella otra cosa que el idioma, conservado entre los polacos para el comercio de la vida intima y para dirigirse a Dios, único consuelo de los afligidos en el mundo. Pues bien, el príncipe de Bismarck, que no perdona medios tratándose de la guerra al catolicismo, baciendo blanco de sus iras a monseñor Ledochowski, ostenta los efectos de su poder contra la Iglesia $y$ contra la nacionalidad polaca a un mismo tiempo. La correspondencia de España, el diario con mayor tirada en la época, dedica al asunto Ledochowski y a la persecución del pueblo católico y polaco varias notas durante 1874 (especialmente las de 4.2., 10.2., 16.4., 18.4., 28.7. de 1874) a pesar de su indiferencia habitual hacia temas de política exterior. Bismarck subrayaría en sus memorias la importancia del factor polaco en los orígenes del Kulturkampf: Der Beginn des Culturkampfes war für mich überwiegend bestimmt durch seine polnische Seite, (BISMARCK, Otto von: Gedanken und Erinnerungen, Stuttgart 1898, vol. II, pág. 127).

${ }_{34}$ LC, 1873, tomo II (7.-12.), pág. 9. El primer tomo de 1874 dedica dos artículos (la persecución en Alemania, La persecución el Polonia) a las medidas de Berlín y San Petersburgo contra los católicos polacos. En 1876 la persecución en Polonia vuelve a estar de actualidad: al calor de la polémica en torno al artículo XI de la Constitución sobre la libertad de cultos, los partidarios de la Unidad católica acuden a las desgracias de los católicos polacos en Alemania o Rusia para justificar su intransigencia (vid. El libro de la Unidad Católica, Madrid, 1876); J.B. Padilla, traductor del folleto La persecución religiosa en Alemanial por P.F., Madrid 1876, afirma en la presentación: El Imperio de Alemania, al tratar al clero católico tan arbitrariamente como lo bace, desmiente de una manera terminante lo que ba tantos años nos dicen los filósofos, 'que Alemania es el país clásico de la libertad y la tolerancia'. 
dejado de intervenir en España tras la retirada de la candidatura Hohenzollern. En septiembre de 1872 parece evidente que la dinastía saboyana agoniza. ¿Intentará Bismarck una solución «a la prusiana» con la excusa de evitar el caos? El miedo a una nueva candidatura alemana no era una quimera ${ }^{35}$ : pero no explica por sí solo la desconfianza con la que los intelectuales de izquierda vieron la conferencia de Berlín. Como en el caso de los carlistas, también aquí actuaba un recuerdo histórico cuya sombra se proyectaba sobre el presente. Aquel mismo año se cumplía - caprichos del azar- el primer cincuentenario del Congreso de Verona.

Los soberanos del Norte se reúnen, [tienden] sus siniestros ojos a Occidente..., pero no olvidéis que son los descendientes de los tres verdugos de Polonia, clamaba en septiembre de aquel año un orador republicano del que no tardaremos en ocuparnos $^{36}$. La frase contiene dos referencias históricas diferentes; la primera, los repartos de Polonia, ya la hemos encontrado en la prensa carlista; la segunda, la alusión a la 'siniestra mirada' que los emperadores dirigen al Occidente, ningún liberal podía escucharla en 1872 sin recordar la humillación de cincuenta años antes. ¿Pretendían los Soberanos del Norte repetir la invasión de 1823? ¿era una brutal represión, como la que habían sufrido ya por dos veces los polacos, lo que se gestaba en los antros imperiales? Evidentemente, hoy sabemos que lo que menos interesaba a Bismarck era un triunfo carlista, por no hablar de una restauración monárquica en Francia; pero los recuerdos históricos pueden distorsionar la realidad hasta hacerla irreconocible. Muchos liberales creían que estas conferencias no eran sino otros tantos eslabones en la cadena forjada por aquellos augustos personajes para aberrojar a la Europa de Occidente ${ }^{37}$. Así los explicaba El Debate, diario dirigido por Galdós: Unos ven en ella una renovación de la antigua Santa Alianza contra las libertades de los pueblos; otros suponen que es la liga del Norte contra el Mediodía, una guerra de las razas slava y germánica contra la lati$n a \ldots{ }^{38}$. Más adelante, esa alianza se considerará causa del aislamiento de la república: El convenio tácito o explícito, formalizado o simplemente sobreentendido entre los tres Emperadores, de Alemania, de Rusia y de Austria en su entrevista de Berlín, ba sido y está siendo a mi juicio el más grave de los obstáculos que basta boy se ha opuesto (...) a que la república española sea oficialmente reconocida. Poco después de la entrevista famosa tuve el bonor de decirle al Gobierno, y los hechos han confirmado de sobra lo

35 Vid. Espadas Burgos (1990), «La Restauración y el intervencionismo prusiano» (págs. 9 a 44).

36 Discurso de 18.9.1872, en CASTELAR, Emilio: Discursos políticos dentro y fuera del Parlamento (1871-1873), Madrid 1873, pág. 465. También dedicó un artículo a la conferencia: «Maniobras imperiales", agosto de 1872. Castelar recordaba el centenario del reparto: Polonia se levantó porque ninguno de sus bijos ba podido convenir todavía en la legitimidad del tremendo crimen que la sacrificó y destrozó. En CASTELAR, Emilio: Cartas sobre política europea, Madrid 1876, pág. 343.

37 Navarro, Isidoro: «Entrevista de los Emperadores de Austria, Prusia y Alemania», RdE, tomo XXXII (Madrid, 5.-6. 1873), pág. 522.

${ }^{38}$ El Debate, 10.8.72. Vid. también 30.8.72, y 9.9.72: España vive alerta, aunque al parecer dormida; pero su despertar fue siempre el del terrible león («La venta de Cuba»).

Hispania, LXII/1, núm. 210 (2002) 167-220 
que entonces fue una simple conjetura, que los tres emperadores babian, a mi juicio, pactado entre sí la resurrección (...) de aquella Santa Alianza, que de 1815 a 1830 y aún más tarde se opuso a todo género de progreso político en Europa... ${ }^{39}$. El miedo a una intervención armada en los asuntos de España alcanzó su punto álgido en el verano de 1873, cuando se promulgó el decreto de piratería de SalmerónOreyro, momento en el que basta los bombres de más templadas ideas se sintieron ofendidos y temieron la reproducción de las vergüenzas y los horrores de $1823^{40}$.

La Carcajada, revista federal barcelonesa especializada en la caricatura política, ofrece las ilustraciones más sugerentes a propósito de esta conferencia y de sus implicaciones en dos grabados publicados en septiembre de 1872. En la primera caricatura, el káiser contempla a Bismarck jugando con unos muñecos que representan al rey y a los políticos españoles, colocados sobre un teatrillo de títeres. A sus pies, un león famélico yace encadenado; detrás hay un telégrafo que envía órdenes directas desde Berlín a Italia y España. Bismarck sostiene un mapa de España; un detalle interesante que significa la introducción de un poderoso icono: el mapa nacional desgarrado por las potencias ${ }^{41}$. El segundo grabado, una escena doble, es más optimista: la parte superior, titulada Conciábulo de los tres Emperadores en Berlín, representa a estos personajes que, ayudados por Víctor Manuel (y... ipor el papa!), forjan armas y cadenas en una tenebrosa fragua; a sus pies, la República enciende la mecha que prenderá unos barriles repletos de petróleo. La parte inferior lleva la leyenda post nubila foebus, y muestra una escena festiva: hombres y mujeres ataviados con trajes populares de toda Europa bailan alrededor de una hoguera en la que arden los atributos imperiales $^{42}$. La escena tiene sabor añejo; recuerda tiempos ya pasados: la Primavera de los pueblos.

\section{LA ORATORIA DE CASTELAR}

Aquel republicano a quien hemos oído advertir sobre la siniestra mirada de los verdugos de Polonia no era otro que Emilio Castelar, el más admirado ora-

\footnotetext{
39 Despacho de Patricio de la Escosura, encargado de negocios en Berlín, de 15.7.73, extraído de Espadas Burgos (1990), pág. 18 y 19. Existe pues un revival del tópico de la Santa Alianza en el verano republicano de 1873. La Igualdad advierte en 29.7.73: cestarán pensando las potencias del Norte, nueva Santa Alianza, en intervenir en España?. El tópico continuaba vivo en vísperas de la Restauración, cuando la $R d E$ se indignaba contra los liberales que confiaban triunfar en la guerra carlista mediante la venida de los 100.000 bijos de Hobenzollern, de Rodulfo o del demonio: RdE, tomo XXXIX (Madrid, 7.-8. 1874), pág. 415.

40 PUig Campillo, Antonio: La intervención de Alemania en el Cantón murciano, Cartagena 1918, pág. 81.

41 «Colección de muñecos castellanos que sirven de juguete a unos prusianos», La carcajada, 12.9.72.

42 Ibidem 11.9.72.
}

Hispania, LXII/1, núm. 210 (2002) 167-220 
dor de la época. Su discurso, lleno de referencias históricas y de hipérboles temerarias, capaz de contradecirse varias veces a lo largo del mismo párrafo sin disminuir su poder de convicción, era el modelo alabado, temido y copiado por sus contrincantes. Muchos de los tópicos del momento provienen de su verbo florido: creemos no equivocarnos al afirmar que fue precisamente a través de la oratoria castelarina como la expresión 'Polonia del Mediodía' se introdujo en la España del Sexenio.

Confrontadas sus ideas con la piedra de toque de la praxis política, durante el decisivo 1873 Castelar se distinguirá por su insistencia en el orden y las acusaciones de demagogia que lanza sobre la izquierda de su partido. Redactor del proyecto de constitución federal, se opondrá luego a su aprobación. De hecho, Castelar será, según Jover ${ }^{43}$, uno de los primeros en contribuir con su desilusionada pluma y poderosa elocuencia a forjar el mito historiográfico del 73, al exagerar hasta el límite los desordenes meridionales de aquel año y convertir la república federal, por la que había luchado - pero sólo, iay!, en las puras esferas de la teoría - en paradigma del caos. Su posibilismo durante la Restauración contrasta con la oposición frontal que mantuvo contra la monarquía democrática, pero extranjera, de Amadeo. Siguiendo una evolución inversa a la de Galdós, adoptará posturas cada vez más conservadoras, aun sin abandonar la etiqueta republicana. Si hay alguna herencia intelectual de Castelar que merece la pena subrayar, ésta es sin duda su contribución a la formación del imaginario nacionalista español: aunque la derecha del XX se arrogará el derecho exclusivo a salvar a la Patria, lo cierto es que sus precedentes decimonónicos reconocidos prefirieron valores como la Unidad católica, la Tradición y la Legitimidad. La retórica patriótica de Castelar, su amor al orden, su respeto a los cimientos de la sociedad, su vago misticismo cristiano y su obsesión por la raza latina como fundamento de la nacionalidad española y del panhispanismo, aportaron un ideario fácil de digerir por la derecha novecentista, que le perdonará pronto su republicanismo teórico y conservador.

Que la expresión "Polonia del Mediodía» no era nueva en 1872 lo demuestra el propio Castelar, que ya la utilizaba en un artículo juvenil que lleva el interesante título de El patriotismo español y la temprana fecha de 1859. Eufórico por la ola de entusiasmo que acompañaba la guerra de Tetuán, Castelar retaba a los que quisieron convertir a España en la Polonia del Mediodía, y les advertía que en una guerra nacional, por nuestra independencia, por nuestros hogares, volveríamos a ser los héroes de 1808, volveríamos a escribir una iliada en las piedras de nuestras ciudades ${ }^{44}$. Conviene subrayar el contexto optimista en que se inscribe la cita: es una forma irónica de referirse a los proyectos de Napoleón contrariados

\footnotetext{
43 Cfr. nota 97.

44 CASTELAR, Emilio: Miscelánea de bistoria, de religión, de arte y de política, Madrid 1874, pág. 211. En otro lugar afirmaba a propósito de la misión española en África: Dios no ha querido que España sea la Polonia del Mediodía, porque Dios la necesita para formar la trama de la vida europea (pág. 151).
} 
por la resistencia española. Por eso resulta tan llamativo el contraste con el pesimismo que adquirirá dos décadas después, cuando los que utilicen el tópico piensen que existe una posibilidad real de que España sea despedazada.

Polonia había sido para Castelar, como para todos los liberales, símbolo de los pueblos oprimidos por el despotismo. La identificación del zar con el tirano por antonomasia le permitirá incluso emplear el nombre de su capital como modelo genérico de represión: ... cuando un capitán general convierte aquella ciudad en una Varsovia, clama Castelar en las cortes de 1869, quejándose del rigor con que las fuerzas del orden habían actuado en Barcelona ${ }^{45}$. Desde sus primeros artículos, en los años de la guerra de Crimea, hasta los que dedica a las crisis balcánicas de los 70, la denuncia de Rusia como el mayor enemigo de la libertad de Europa occidental es una constante de su discurso. Dedicará dos libros de política internacional a cultivar su pasión antirrusa $a^{46}$ : Rusia, que ha devorado veinte pueblos para formar una verdadera ergástula de esclavos ${ }^{47}$, es una grave amenaza para la civilización; frente a su paneslavismo egoista ${ }^{48}$ deben formar un frente unido las razas germánica y latina. La resurrección de Polonia, a la que considera el mejor contrapeso de Rusia dentro de la familia eslava, es un paso imprescindible en la política de contención del oso ruso. La manía rusófoba de Castelar era de tal envergadura, que llamaba la atención en el extranjero: un crítico alemán hizo de ella uno de los principales argumentos de su juicio - negativo- sobre el tribuno, burlándose ante sus lectores del «miedo instintivo" al ruso que el republicano español intentaba contagiar a los alemanes ${ }^{49}$.

En vísperas de la Gloriosa coincidían en París los opositores al régimen isabelino con los polacos fugitivos de la represión rusa. En una crónica de esa época, Castelar relata un paseo por la Exposición Universal de 1867. Atraído por una melodía de Chopin - ese Murillo de la Música - que interpreta un joven rubio, de ojos azules, de largas melenas, expresando en su rostro la tristeza resignada de

\footnotetext{
45 Discurso pronunciado el 5.10. 1869. En: CASTELAR, Emilio: Discursos parlamentarios en la Asamblea constituyente, Madrid ( $5^{\text {a }}$ ed., s.a.), tomo II, pág. 237.

46 CASTELAR, Emilio: La cuestión de Oriente, Madrid 1876; y La Rusia contemporánea, Madrid 1881.

47 En Castelar (1881), pág. 215.

48 Todo el mundo sabe (...) que Rusia, en su amor supersticioso por las razas esclavonas (sic) exceptuaba siempre la infeliz Polonia. CASTELAR, Emilio: Historia del año 1883, Madrid 1884, pág. 61. Paradójicamente, esta incompatibilidad entre polacos y rusos, que desmentía el argumento de la afinidad racial, se solventaba a veces negando el carácter eslavo a los rusos: Polonia, slava, y Rusia, mejor dicho Moscovia, finesa y uraliana; aquella dominada y esta dominadora, no pueden unirse nunca. Son dos metales diferentes, soldados, pero no fundidos (Albert de Álvarez (1863), pág. 28). Cfr. nota 134.

49 Der Spanier hat eine instintive Furcht vor dem Russen. Castelar füblt sich von einem geheimen Grauen durchfröstelt, wenn er der panslavistischen Zukunftpläne gedenkt. Diese Russenfurcht wünscht er vor allen dingen den Deutschen einzuimpfen in der Einleitung seiner «Erinnerung an Italien». En CONRAD, M. G.: Spanisches und Römisches: Kritische Plaudereien über Don Emilio Castelar, Pio Nono, den vaticanischen Gott, und andere curiose Zeitgenossen. Breslau 1877. Se refiere a unas cartas que Castelar dirigió en 1876 al profesor Schanz de Leipzig, siguiendo el modelo de las célebres misivas intercambiadas por Renan y Strauss; en ellas advertía a los alemanes del peligro paneslavista.
} 
un mártir, el español se dirige al pianista: Yo no pude menos que manifestarle mi admiración por su destreza y por su exquisito sentimiento. Apartando modestamente la conversación de sí, la fijó en la melodía que acababa de tocar, haciendo de ella mil entusiastas encarecimientos. 'CSois ruso?' - le pregunté - 'No, me dijo, soy polaco' Debió notar en mí un sentimiento de compasión que me fue imposible reprimir. - 'Amo a mi patria con delirio', me dijo bajando la voz, como si temiera que nos escucbase un guardián de la exposición, un ruso, que a algunos pasos de nosotros estaba de pie, envuelto en capotón de pana negra, calzado con botas de montar, sobre el cual caían unos pantalones bombachos, ceñido el cuello con una corbata carmesí, la cabeza con una gorra de pieles - 'Amamos la patria como amamos a nuestras madres, le dije; yo amo también a mi patria con delirio'- '¿Sois americano?' me preguntó - 'No, le respondí; soy español'. -iOb! Cuantas veces bemos invocado nosotros los nombres sacratísimos de Zaragoza y Gerona'. 'Confiad en vuestro derecho, le dije. Mirad si parecía imposible la independencia de Italia; Italia es boy independiente's0. Aunque la conversación se presenta como si fuera un suceso real, el carácter arquetípico de sus protagonistas hace pensar más bien en una escena simbólica, construida a partir de tópicos: por lo pronto, en ella aparece ya el heroísmo zaragozano como ejemplo para Polonia. No obstante, la simpatía por la nación de Kosciusko, tan arraigada entre los intelectuales españoles, no excluía un reproche: si aquel reino no sobrevivió a los repartos, la culpa no fue únicamente de la ambición de sus vecinos; la división de los polacos contribuyó a la ruina de la nación. Un pueblo sin orgullo merece la suerte de Polonia, llegará a afirmar Castelar a propósito de Francia, especulando con la idea de que hubiera aceptado la continuidad del Imperio después de Sedán ${ }^{51}$. En su oratoria, rica en oposiciones forzadas, el ejemplo polaco sirve como antíteșis de la permanencia de España, superviviente de la catástrofe gracias al holocausto patriótico. Un estudio de la oratoria castelarina nos permite observar la transformación del tópico desde el uso optimista de los inicios del Sexenio hasta el sombrío dramatismo que la expresión adquiere a medida que los acontecimientos sugieran la posibilidad de una catástrofe análoga a la polaca.

Un primer grupo de alusiones a Polonia, las más optimistas, lo forman las abundantes referencias contenidas en los hiperbólicos elogios a la Gloriosa. Según Castelar, la noticia del levantamiento provocó un estremecimiento de alegría que atravesó las entrañas de todos los pueblos oprimidos, desde la Francia imperial hasta la desmembrada Polonia ${ }^{52}$. Al tener noticia de los sucesos de Cádiz, los pueblos

so Castelar (1875), pág. 209.

51 Castelar (1884), pág. 112.

52 Discurso de 8.6.1872. En Castelar (1873), pág. 385. Sobre la repercusión de la revolución en Alemania y Rusia: ÁlVAREZ GuTIÉRREZ, Luis: La revolución de 1868 ante la opinión pública alemana, Madrid 1988; y «El Zar y su gobierno ante la revolución española de 1868», en Hispania, XLVI/164, Madrid, 1986. Hemos encontrado, pese a nuestro deficiente conocimiento de la literatura polaca, dos alusiones a los sucesos españoles en las narraciones de Henrik Sienkiewicz. La primera aparece en un cuento - Señor secretario-, que transcurre en vísperas de la guerra de 1870: el señor

Hispania, LXII/1, núm. 210 (2002) 167-220 
muertos palpitaban en sus sepulcros, los pueblos esclavos saltaban bajo sus cadenas. Polonia creyó que podía recoger sus miembros esparcidos $\{\ldots\}^{53}$. El miedo que la revolución española provocó en los tiranos bastó para proporcionar a Polonia un pequeño alivio en su desgracia: Yo me he encontrado [en septiembre de 1868] en el Congreso de Berna, donde había representantes de todos los partidos liberales de Europa. Llegaban los telegramas del primer movimiento de Cádiz, y me decía un polaco: 'el emperador de Austria seguirá los consejos del príncipe Czartorisky, e irá a la Gallitzia, la cual le hará un gran recibimiento si no triunfa la revolución en España'. Coincidió el triunfo de la revolución con la salida del Emperador de Austria; fue éste a la estación, en donde bumeaba el tren que habia de conducirle a la gran provincia de Gallitzia, a aquel miembro de Polonia a quien había dado cierta autonomía. Y esa porción del reino de Polonia, inmediatamente que supo del triunfo de la revolución española, no quiso recibir al Emperador, y los individuos de su Gabinete le tuvieron que decir que no emprendiese su viaje a Gallitzia, que sería muy mal recibido, porque habia alli grandes esperanzas, muy grandes, de que pudiera salvarse toda Polonia desde el momento en el que había visto el gran espectáculo de la nación española. Y últimamente ban tenido que hacer el Emperador y sus cortesanos la concesión para ellos más terrible, la concesión de la lengua polaca a la Gallitzia para sus actos oficiales ${ }^{54}$.

Pronto el orgullo dio paso a la vergüenza. Si la decisión de las Cortes a favor de la monarquía contrarió al republicano, las renuncias de los sucesivos candidatos humillaron al patriota. No quiero para mi patria príncipes extranjeros; no quiero que mi patria sea la Polonia del Mediodíass, exclama Castelar en uno de aquellos debates, introduciendo, si no nos equivocamos, el tópico polaco en la oratoria del Sexenio. Muy pronto dejará de pertenecerle en exclusiva: la interpretación «moral» del tópico, la que culpaba a los polacos de la desmembración de su patria, será del agrado de los conservadores. Apenas dos meses después de que Castelar invocara el recuerdo de los repartos en contra de la monarquía, García Ruiz - líder de los republicanos unitarios opuestos a los federales entre los que militaba Castelar - esgrimía el tópico polaco en contra de la federación: Yo creo que (...) la proclamación de la República federal en España sería boy

Zolziekiewicz entretiene su ocio con la lectura de un folletín erótico-político de signo anticlerical, llamado Isabel de España, o los Misterios de la corte de Madrid, y se imagina transformado en los amantes regios, Marfori o Serrano. Esta lectura fomenta en él un ramplón anticlericalismo. El drama del polaco alistado bajo una bandera extranjera, sugerido en el cuento anterior, se desarrolla en Bartek el triunfador, que comienza en vísperas de la guerra franco-prusiana. El narrador se refiere irónicamente a la aldea de Pongenbin (Poznan), que había declarado la guerra a Francia, habiéndose tomado a mal la cuestión de quién había de subir al trono de España.

53 Castelar, Discursos parlamentarios en la Asamblea constituyente, op. cit., tomo I, pág. 28.

${ }^{54} \mathrm{Ibídem}$, tomo II, págs. 95-96. Discurso pronunciado en 14.6.69.

ss Ibídem, tomo I, pág. 71. Discurso del 8.3.69 contra la candidatura del duque de Montpensier. 
señal de la más espantosa anarquía (...) Yo no quiero que sobre ella se pueda decir, imitando a Kociusko, el 'Finis Hispaniae's6.

La aparición del tópico coincide con un cambio de tono. Ya no se trata de ponderar los méritos de la revolución española, sino de advertir de los perniciosos efectos del rumbo que toman los acontecimientos posteriores. La polarización de las facciones en torno a los candidatos dividía a los septembristas; la intervención de las potencias ${ }^{57}$ mostraba lo lejos que estaba España de ser esa influyente nación, capaz de estremecer de miedo a los tiranos y de alegría a los pueblos oprimidos, que de forma tan ingenua cantara poco antes el propio Castelar. Desde el principio, la candidatura saboyana despierta en él una invencible hostilidad: Yo lo digo, yo lo declaro; estoy resuelto, señores diputados, con mi palabra, con mi voz, con mis escritos, con todos los medios que tengo, a exaltar hasta el delirio, hasta el frenesí, basta el fanatismo, el sentimiento nacional, exclama indignado por la humillación que supone coronar a un extranjero ${ }^{58}$. A un historiador como él, la elección del rey, la desunión de los partidos y las presiones extranjeras sólo podían traerle el recuerdo de las dietas que jalonaron la crisis del reino polaco desde la guerra de Sucesión de 1733-35 hasta su desintegración. En noviembre de 1870, todavía bajo la impresión de la derrota francesa, cuando Castelar se oponga en las Cortes a la candidatura de Amadeo de Saboya, buscará en la tragedia polaca un sólido argumento en apoyo de sus ideas: Un crimen enorme se cometió a mediados del siglo anterior, un crimen que bace dudar de la justicia en la bistoria. Una gran nación, caballeresca por temperamento, gloriosa por sus tradiciones, centinela avanzado de la civilización en el Norte, inquebrantable escudo contra el cual se estrellaron cien invasiones, fue asaltada, presa, descuartizada viva, y repartida en sangrientos despojos entre los poderosos del mundo, que tanta veces ban querido justificar la injusticia con la victoria. Mil veces esos miembros disyectos y sepultados se han querido levantar de sus buesos. Mil veces, como si los restos de los muertos se animaran a las lágrimas de los vivos, se ban levantado legiones innumerables de mártires, que ban caído en la eternidad al plomo moscovita... El crimen ha engendrado una serie de crimenes. La desgracia ba sido una cadena infinita de míseras desgracias. Pero Polonia ba muerto, y en vano aguardamos el día de su resurrección. Sin que el crimen se justifique nunca, porque es injustificable, se excusa; no se excusa, se explica por aquella aristocracia orgullosa, inaccesible a toda idea de compasión hacia sus siervos; por aquel espíritu católico, que babía degenerado en espíritu jesuítico; por aquellas Asambleas, aquellas Dietas, tomadas de todas las pasiones, e incapaces de llegar a ninguna solución ni a ningún

56 Discurso de 13 de mayo de 1869 a favor de la república unitaria. En García RuIz, Eugenio: Historia de la Internacional y del federalismo en España. Madrid 1872, pág. 91. Cfr. infra, discurso de León y Castillo en las Constituyentes del 73, nota 88.

57 Sobre todo las presiones prusianas y francesas. Estas últimas, contra la proclamación de la república primero, oponiéndose luego a la solución Orleans y vetando después la candidatura prusiana. Vid. Espadas (1990), cfr. nota 35; y Rubio (1989), 'Las grandes potencias y la vacante del trono de España', vol. II, pág. 618 y ss.

58 Castelar (1873), págs. 48-49. 
acuerdo; por aquellas zozobras que en todas partes lanzaban, en todas las potencias, sus continuas elecciones de reyes extranjeros, de reyes buscados en Francia, en Alemania, en Suecia, en todas las monarquías, menos en Polonia; iab! en Polonia, herida de muerte, no sólo por las armas de los tiranos extranjeros, sino por el virus interior y corrosivo de sus propios errores. Yo, en mi amor a este suelo, en el cual tengo las raíces de mi vida, los buesos de mis padres, y en el cual pienso dormir el sueño de la muerte; yo, viendo el error y la tenacidad en el error de que están poseídos nuestros gobiernos, yo no me atrevo a pedir a los hombres, sino a Dios, que evite a España el cáliz amarguísimo de una pasión semejante a la pasión de Polonia ${ }^{59}$.

He aquí lo que Galdós quería decir cuando hablaba de motivos para repartir España más graves que los que habían conducido al Finis Poloniae: la disgresión histórica de Castelar sirve para atacar al gobierno (y en concreto a Prim, al que hace responsable de... ila derrota y la humillación de Francia!). En las vacilaciones del discurso - el crimen no se justifica, pero se excusa; no se excusa, pero se explica - se reflejan las contradicciones del orador. Por un lado, la revolución ha exaltado su nacionalismo; sin embargo, la vacante del trono español provoca la intervención extranjera y un inacabable desfile de candidatos desdeñosos; la asamblea, dividida, termina por elegir a un rey que no cuenta con el respaldo general. De ahí el mote de rey de los 191 que se aplicará a Amadeo, en alusión a la exigua mayoría que votó su candidatura.

Entre la euforia y el pesimismo, los discursos de Castelar comprenden un tercer grupo de alusiones, en el que los extremos se equilibran: el diagnóstico de la situación es tan grave como el de la de Polonia en 1772, pero la reacción del pueblo, que será la de 1808 , salvará a la Patria. Un rasgo interesante de estas citas es que introducen un elemento que remite también al texto de Galdós: Zaragoza como antítesis de Polonia.

Curiosamente, la ciudad también tenía reservado un lugar propio en el imaginario colectivo polaco. El profesor Kieniewicz ha explicado la trascendencia que tuvo la participación de tres regimientos de infantería de la Legión del Vístula en los dos sitios de la ciudad: este hecho provocó incluso un sentimiento de culpa que influiría en la formación de una especie de 'complejo español'. Los sitios de Zaragoza aparecen también en la obra literaria de Zeromski (y en la de Jan Potocki, donde sirven de marco al hallazgo del manuscrito), y su recuerdo llega hasta las Brigadas Internacionales, cuando un batallón polaco tomó el nombre de Palafox ${ }^{60}$. Del lado español, Zaragoza era un símbolo para el nacionalismo de talante liberal. Del nombre del río se derivaba el de la Península y el del pueblo que constituía el pretendido sustrato de la «raza»; era

59 Discurso pronunciado el 3.11 .70 sosteniendo un voto de censura al Ministerio por la presentación de la candidatura del príncipe Amadeo de Saboya a la corona española. En Castelar, Discursos en la Asamblea constituyente, op.cit., tomo III, págs. 355-357 (hemos corregido una errata evidente). Cfr. la opinión desfavorable a España como modelo político para Polonia expresada en el Parallèle de Lelewel, en Kieniewicz (1988), op.cit., págs. 59-61.

60 Vid. Kieniewicz (1988), pág 74 y ss. 
además capital de Aragón, cuya tradición «liberal»y «federal» se oponía tópicamente al «absolutismo» y "centralismo» atribuidos a Castilla. A esto se añadía la gesta de 1808-1809, y en el caso de Castelar, una circunstancia personal: había sido elegido diputado en las cortes de 1869 por esa circunscripción. Zaragoza es pues omnipresente en la oratoria castelarina, incluso en ocasiones en que apenas se justifica por el tema del discurso: por ejemplo, cuando defendiendo la abolición de las quintas proclame la gran sentencia que Zaragoza escribió sobre sus muros, y que toda Europa admira, y que todos los pueblos del mundo ban reconocido: De las grandes naciones que pelean por la libertad y la independencia, es posible conquistar el cadáver, pero no es posible conquistar el alma ${ }^{61}$. Zaragoza, es, en fin, poema vivo de independencia, el ejemplo eterno donde aprenden todas las naciones oprimidas, desde Bobemia hasta Polonia... cómo se pelea por la dignidad nacional, cómo se muere por la libertad y por la patria ${ }^{62}$.

Durante los cuatro primeros años del Sexenio, Castelar puso de moda el ejemplo polaco. Torció luego su significado originario, y de expresar exaltación patriótica, el tópico degeneró en sentencia pesimista, o al menos fatalista: sólo un holocausto podía salvar a España de un destino atroz. Por último, introdujo la antítesis, utilizada luego por Galdós (y tantos otros) que oponía la desgraciada Polonia a la heroica Zaragoza (o, en términos fluviales y poéticos; el Vístula al Ebro). La conmemoración del centenario de 1772 y la inquietud provocada por la conferencia de Berlín, de la que participaba por distintos motivos casi todo el espectro político, haría lugares comunes de sus figuras retóricas. En la primavera de 1872 , cuando se empiece a hablar de una alianza imperial, el tópico polaco había cristalizado ya en la oratoria de Castelar en la forma exacta que utilizará Galdós dos años después: Sin Zaragoza, sobre cuya tierra ba caído la sangre de tantos héroes y cuyo nombre invocan todos los pueblos oprimidos, nuestra patria sería como la Polonia del Mediodía ${ }^{63}$.

\section{GALDÓS PERIODISTA}

En los años que siguieron a la Gloriosa, Galdós se dedicó al periodismo. Llegó incluso a dirigir dos importantes publicaciones: El Debate y la Revista de España (de febrero de 1872 a noviembre de 1873). Fundada por Albareda pocos meses antes de la Revolución, esta última era un brillante ejemplo de la renovación del periodismo propiciada por la Constitución de 1869. Caracterizada por su rigor intelectual e informativo, en la Revista de España colaboraban las mejores plumas del país. Incluía obras literarias, filosóficas y científicas,

\footnotetext{
${ }^{61}$ Castelar, Discursos parlamentarios en la Asamblea constituyente, op.cit., tomo III, pág. 169. Cfr. con Kieniewicz (1988), pág. 77: Les Polonais connaissaient bien le mythe espagnol d'une lutte menée jusqu'au bout, symbolisé par Sagonte, Numance et Saragosse.

62 Castelar (1873), op. cit. , pág. 99.

${ }_{63} \mathrm{Ibídem,} \mathrm{pág.} \mathrm{317.} \mathrm{Discurso} \mathrm{pronunciado} \mathrm{en} \mathrm{Sevilla,} \mathrm{en} \mathrm{abril} \mathrm{de} 1872$.
} 
reportajes de actualidad y dos secciones fijas, Revista politica del interior y del exterior. Galdós publicó en ella con cierta asiduidad durante los primeros años: entre otras cosas, catorce crónicas de política interior. El éxito de sus novelas (que aparecieron por entregas en la Revista) le animó a dedicarse de forma casi exclusiva a la literatura, espaciando cada vez más sus colaboraciones a partir de la aparición de la primera serie de los Episodios nacionales (cuyo nombre, por cierto, le sugirió Albareda, según cuenta Galdós en sus Memorias de un desmemoriado). La Revista de España defendía los principios de Septiembre. Moderada y conservadora, preocupada por el fortalecimiento de las instituciones, abogaba por la unión de los partidos en torno a la monarquía democrática. En 1873 recibiría la república sin entusiasmo; partidaria del orden, apoyará a Castelar - colaborador habitual de la publicación- durante ese año crítico. En 1874 saludará el golpe de Estado como remedio ineludible: precisamente en ese momento sus dos propietarios asumieron altas responsabilidades políticas - Albareda, gobernador civil de Madrid; León y Castillo en la subsecretaria de Ultramar-. En general, puede decirse que su línea editorial coincide con la evolución ideológica que sufre durante aquellos años el propio Galdós (o, para el caso, con la de Castelar, que en teoría partía de orígenes más progresistas).

Una particularidad de la Revista es la frecuencia con que publica artículos monográficos de política internacional. La información acerca de Polonia es relativamente abundante. A lo largo de 1871 se publica un largo Estudio bistórico diplomático sobre el Imperio ruso que se justifica por un acontecimiento contemporáneo: la reforma de los artículos del tratado de 1856 que regulaban la navegación en el mar Negro. Por supuesto, no falta un análisis de la crisis del Estado polaco, comparada desfavorablemente con las que había superado el Imperio otomano: Si prescindiendo la Polonia de sus luchas intestinas y en interés de su propia conservación, cual la Turquía, bubiera aparecido unida y compacta, indudablemente que como ella bubiera triunfado de Rusia [...], pero en extremo enconados los ánimos y por demás exacerbadas las pasiones, para salvar a la desventurada nación de una ruina inevitable, la Francia, a imitación de lo becho en 1737, fomentó una nueva guerra entre Turquía y Rusia ${ }^{64}$. Unas pocas páginas mas allá, en la crónica de política interior, Galdós analiza la crisis española, criticando las facciones radicales, que bacen depender su actitud y su política de soluciones extranjeras, y más que nada del giro que tomen los asuntos en Francia... ${ }^{65}$. En los meses siguientes, mientras la Revista denuncia la división del partido que ha traído al rey y el peligro que corren las provincias de ultramar, las siguientes entregas del artículo describen con detalle los males que condujeron al Finis Poloniae: su decadencia, [...] los vicios de que adolecía su constitución interior..., [...] sus soberanos destituidos, proclamados y

${ }^{64}$ BORSO, Emilio: «Rusia, sus tendencias y aspiraciones. Estudio histórico diplomático», RdE , tomos XIX ( Madrid 3.-4. 1871), XX (5.-6. 1871) y XXI (7.-8. 1871). La cita corresponde al tomo $\mathrm{XX}$, pág. 112.

6s RdE, «Rpi», tomo XX (5.-6. 1871), pág. 131.

Hispania, LXII/1, núm. 210 (2002) 167-220 
vueltos a sustituir...66. A finales de 1871 aparece un artículo de Romero Ortiz ${ }^{67}$ sobre un tema de moda: la raza como base de la organización política. La guerra franco-prusiana y la culminación de los procesos unificadores en Alemania e Italia se interpretaban como resultado de fuerzas de atracción y repulsión provocadas por instintos raciales: Hoy por boy, lo que vemos es una propensión creciente a formar grandes nacionalidades, es decir, una tendencia constante, universal, poderosa, irresistible de las razas hacia su unidad...(...) La Europa está llamada a dividirse por razas con ciertas modificaciones que impone la geografía y que serán determinadas por la libre y espontánea voluntad de los pueblos. Según el proyecto del veterano progresista, Europa ha de constituirse en diez naciones racialmente homogéneas: entre ellas Polonia, separada del resto de la raza «slava» y de Rusia ${ }^{68}$. Por supuesto, la nación mártir despierta la piedad del autor: La Polonia, la infeliz Polonia, aberrojada, ametrallada, dispersa y proscrita, se ha resignado a sufrir los rigores de su aciaga suerte... No bay pueblo alguno en la tierra que inspire tan profundas y universales simpatías como ese pueblo desventurado y mártir, cuyas candentes lágrimas riegan la tierra entristecida y se extiende desde el Oder hasta el Dniepper. Pero las causas de su ruina habían sido profetizadas desde antiguo por los más lúcidos: La discordia traerá sobre nosotros la servidumbre, anunció Pedro Skanga; Si no renunciáis a vuestros privilegios personales, la república llegará a ser presa de las naciones extranjeras, advirtió Casimiro a los nobles. Dividida entre clanes egoístas, traicionada por sus hijos, $e l$ águila blanca moribunda y ensangrentada sirve de pasto a los buitres del Norte... ${ }^{69}$.

Entre tanto, la monarquía saboyana comienza su segundo año en medio del desaliento. Poco queda ya de la euforia de los primeros meses de la Revista. La angustia ante la desunión de los partidos, y sobre todo la impresión que provoca el levantamiento carlista, alimentan el pesimismo que ya advertimos en la

${ }^{66} R d E$, tomo XXI (7.-8. 1871), págs. 322 y ss.

67 Romero OrTIZ, A.: "Geografía política y diplomática de Europa», RdE, tomo XXIII (Madrid, 11.-12. 1871), pág. 483 y ss.

${ }^{68}$ La tesis racial era cara a Castelar. También él distinguía dos grupos eslavos antagónicos: $E n$ el seno de las razas que parecen próximas a formar una sola familia entre todos sus pueblos, [la Providencia] lanza discordias eternas, como la dificultad insuperable al panslavismo en el norte, entre los eslavos de Polonia y los eslavos de Rusia (en CASTELAR, Emilio: Anales políticos, Madrid, s.a., pág. 79). La idea subyacente era que habría una guerra racial entre las tres principales familias europeas, en la que Polonia podía aliarse con las razas meridionales contra Rusia (cfr. nota 48). Por otro lado, la idea de reconstruir Polonia para debilitar a Alemania parece proceder de Francia. Frente al "pangermanismo» se proponía una alianza latina (bajo hegemonía francesa, por supuesto) y eslava, aunque en este punto existían dos opciones mutuamente excluyentes: la alianza con el Zar o la reconstrucción de Polonia. Vid. reseña bibliográfica sobre el brochure: Que faut il faire pour sauver la France et l'Europe du pangermanisme, por M. Casimir de Samin, en la Revue de deux mondes ( París, tomo XCI, 15.2. 1871, pág. 385). El propio Marx, en el Segundo manifiesto del Consejo General de la Asociación Internacional de los Trabajadores sobre la guerra franco-prusiana (9.9.70), advertía a Alemania que se arriesgaba a una guerra de razas, una guerra contra las razas eslavas y latinas coaligadas.

69 En la iconografía de La carcajada (o La flaca, nombre alternativo de la misma publicación) es habitual la imagen de España presa de pajarracos, p. ej. el grabado «iiiPobre España!!!» de 5.4.72, en el que las diversas facciones están representadas como rapaces que desgarran las vestiduras de la patria.

Hispania, LXII/1, núm. 210 (2002) 167-220 
oratoria de Castelar. Apenas asumido el cargo de director, Galdós escribe una crónica en la que hace balance del primer año de la monarquía saboyana: Épocas de confusión hemos visto aquí, pero ninguna ba igualado a la presente. Caminan los bombres sin norte ni guia por senderos desconocidos, afirma el escritor, que acusa a la desmembración y a las luchas intestinas de los partidos de la gravedad de la situación. Advierte también del peligro que corre la integridad nacional: no puede una sociedad vivir así mucho tiempo, sofocada y ahogada: al fin tiene que buscar una salida por alguna parte, o perecer ante la befa de los pueblos cultos. Galdós repite palabras como catástrofe o fatalidad, y llega a escribir que un empeoramiento del estado de la patria quitaría al alma el consuelo de creer en la Providencia. En esta misma crónica aparece otra comparación semejante al tópico polaco: España podría convertirse en el Méjico de Europa ${ }^{70}$. En los meses siguientes, el pacto de Ruiz Zorrilla con los̀ partidos antidinásticos merece las peores invectivas de la redacción, que ve en todo ello la mano de Bismarck ${ }^{71}$; paralelamente, abundan las noticias acerca de los polacos de Posen, a los que se presenta envidiosos de la suerte de sus hermanos bajo el yugo ruso ${ }^{72}$. Cada vez se habla más de la influencia extrajera en los asuntos españoles ${ }^{73}$; las reformas en las Antillas suponen una humillación: la integridad territorial está amenazada ${ }^{74}$.

\section{CHORIZOS Y POLACOS}

La proclamación de la república eleva el grado de dramatismo en las crónicas de la Revista de España. Se teme que los gravísimos desordenes que tienen lugar en todas las provincias de España lleguen a acabar con la unidad política de la

${ }^{70} R d E$, Rpi, tomo XXIV (1.-2. 1872), pág. 145. La comparación de Amadeo con Maximiliano era un tópico antidinástico. Cfr. GÓMEZ-FERRER, Guadalupe, «El aislamiento internacional de la república de 1873», en Hispania, XLIII/154 (1983), pág. 376.

${ }^{71} R d E$, Rpi, tomo XXV (3.-4. 1872), págs. 130-132, y 286 y ss., firmadas por Galdós.

$72 R d E$, Rpe, tomo XXV (3.-4. 1872), págs. 305 y 459.

73 Especialmente en las crónicas de política interior de Galdós ( $R d E$, tomo XXVI, 5.-6. 1872, págs. 136 y 292). Aún más claramente en El debate, 2.7.72, donde se relacionan los contactos entre los Emperadores del Norte y el rey de Italia con las vicisitudes del Kulturkampf y la sustitución en el gabinete de Madrid del partido conservador por el radical.

${ }^{74} R d E$, Rpi, tomo XXVI (5.-6. 1872), págs. 545 y ss. (F. León y Castillo). En el caso de la $R d E$, la insistencia en esta cuestión estaba provocada por las subvenciones del «lobby» cubano que tan importante papel desempeñó en el advenimiento de la Restauración. Vid. Espadas Burgos (1990), «El trasfondo cubano de la Restauración», pág. 271 y ss. En el episodio Amadeo I (escrito en 1910; cap. V), Galdós se refiere al dinero cubano que recibía Albareda, propietario de El debate y de $R d E$. Cfr. El debate, 9.9.72, donde se denuncia un supuesto intento de vender Cuba a los EEUU, introduciendo el recuerdo de la guerra de la Independencia: La venta no se hará, porque no conocemos todavía al español capaz de bacerla sin levantar contra sí al pueblo en masa, que para defender su bonra y la integridad de su suelo será siempre el pueblo de 1808. Cfr. nota 104. 
nación, y hasta con el nombre y el ser de nuestra patria ${ }^{75}$. Las expresiones utilizadas en esos meses hablan por sí solas: la anarquía devora, la crisis desgarra, se espera la desmembración de España, y llega a plantearse la desgarradora duda de si podrá sonar pronto la última hora de la patria, de si los españoles estarán condenados como los polacos a vivir en esclavitud perpetua ${ }^{76}$. La razón de tanta ruina es que los políticos solo atienden a sus intereses, están corrompidos, ponen la patria en peligro con su mezquino egoísmo. Y todo ello se resume en una palabra: polaquería, es decir, la abundancia de polacos ${ }^{77}$.

$\mathrm{Al}$ igual que su complementario — "chorizo»- el término "polaco» procede del argot teatral de principios del siglo XIX. No guarda relación alguna con los naturales de Polonia sino, al parecer, con cierto padre Polaco que dirigía un grupo de matones que reventaba las funciones de una compañía rival, defendida por los 'chorizos'. Ambas bandas aparecen en $E$ l manuscrito encontrado en $\mathrm{Za}$ ragoza, dentro de «La historia de Pandesowna, jefe de los gitanos»: Potocki los llama «pollacos» y «sorices», y esta ortografía deformada parece que le impide percatarse de la coincidencia del nombre de los primeros con su gentilicio. Por circunstancias que ahora no interesan, 'polaco' pasó a significar también adicto al partido que gobernó en España de 1854 al 56, definición que sigue apareciendo en el DRAE junto a su acepción teatral: en ese sentido político lo utiliza Galdós en la cuarta serie de los episodios, reconociendo que no entiende este remoquete de 'polacos' y 'polaquería' con que se designa toda corruptela, los verdaderos o imaginarios chanchullos de que nos habla la vocinglera opinión ${ }^{78}$. Parece pues que los términos polaquismo y polaquería -ignorados por el diccionario- adquirieron en su vertiente política un significado cercano a "corrupción» o "prevaricación", es decir, bastante próximo al que hoy tiene en el lenguaje popular el eterno complemento del 'polaco': el 'chorizo'. En todo caso, hacia 1872-1873 el término parece haberse desligado ya de cualquier grupo político concreto, ya que entonces se acusará de polaquería a gobiernos radicales o republicanos. Se diría que se ha producido además un desplazamiento semántico que bien puede atribuirse a la influencia de nuestro tópico: en esos días en que tan mala prensa tiene la szlachta - la nobleza adicta al Liberum veto - , el término 'polaco' designa 'egoísmo', 'cortedad de miras' que pone en peligro el futuro de la patria para obtener beneficios particulares. En este sentido lo utilizaba el periódico

$75 R d E$, Rpi, tomo XXX (1.-2. 1873), pág. 548. Las expresiones proceden de la primera crónica publicada tras la proclamación de la república, firmada por Valera.

${ }^{76} R d E$, Rpi, tomo XXXI (3.-4. 1873), pág.126 (León y Castillo); pág. 264 (Valera) y pág. 402 (Albareda).

77 Ibídem, pág. 264 (Valera).

78 PÉrez Galdós, Benito: La revolución de julio, (E.P. 34), Madrid 1986 [1ºd. 1904], cap. VI, pág. 42. Galdós utiliza la expresión de forma diferente a la que propone el diccionario, pues la aplica sobre todo a los escándalos financieros de los gobiernos moderados anteriores al bienio progresista. De hecho, la 'polaquería', que es la política mohosa, rutinaria, se contrapone a esta revolución juvenil, que trae espíritu y modos nuevos (pág. 99). 
dirigido por Galdós en agosto de 1872: Ve [el país] los escándalos vivos en la provisión de cargos públicos, en la concesión de gracias, en la creación de una nobleza grotesca salida de las filas radicales; ve lo que pasa en los preparativos de las elecciones, en la temible cuestión de las huelgas de los obreros; ve que, amenazante el carlismo, conturbadas todas las provincias por la propaganda federal e internacionalista, es disuelto el ejército y mermada en mucho la Guardia civil; y se pregunta el país con bonda amargura: ¿ ¿a dónde vamos? ¿a dónde nos conduce este gobierno? iy aún callan los radicales! iy aún desprecian y toman a risa, con inverecundia y desfachatez las quejas de la patria! iPolacos!79.

En mayo de 1873, justo cuando la prensa ha recuperado la acepción política del término 'polaco', Galdós dedicará el segundo episodio nacional a las luchas entre los «polacos y chorizos» de principios de siglo. La corte de Carlos IV es un intermedio casi bufo entre el heroísmo de Trafalgar y la epopeya que ocupará los ocho restantes episodios de la serie. Madrid se divierte al borde del abismo: el relato gira en torno a las maniobras de las camarillas, y culmina en los sucesos de El Escorial en 1807; sin embargo, la narración comienza con un acontecimiento anterior sin relación aparente con la intriga política: el estreno en 1806 de El sí de las niñas de Moratín, en el curso del cual se produjo una memorable batalla de polacos y chorizos. Creemos que el tópico polaco esconde la clave para descifrar la verdadera dimensión política del episodio, y le confiere una unidad que la crítica ha echado de menos en ocasiones. Galdós describe cómo todos los estamentos - desde la nobleza al pueblo, pasando por el clero- detestan a Godoy y esperan que la salvación venga de la mano de Napoleón: el desastre de 1808 no sobreviene bruscamente; las señales son evidentes para cuantos tienen ojos y oídos, pero la mayoría piensa que son los extranjeros quienes solucionarán los problemas de España. Incluso los dramaturgos que culpan a Godoy del éxito de Moratín y demás poetrastos de polaina, esperan que los franceses, cuando hayan arreglado lo de Portugal, arreglarán a España y se acabará la protección a los malos poetas ${ }^{80}$. ¿Acaso no era muy parecida a esta la actitud de muchos españoles en vísperas del advenimiento de la República?

Una de las claves del episodio es la confusión entre realidad y ficción: confusión que culmina en la escena en la que el actor que representa a Otelo está a punto de matar realmente a su amante en plena función. Pero la metáfora del teatro sirve también para reflejar la circunstancia histórica en que se sitúa la acción: la sombra de Tilsit se proyecta sobre España, grandes y pequeños hablan alegremente del reparto de Portugal, incluso de sacrificar al corso una parte de la nación; entre tanto, en la narración se hace omnipresente una Polonia falsa, teatral, calderoniana, una Polonia de oropel, que no es sino la España

79 Polacos', El Debate, 8.8.1872. La fecha es reveladora: un mes antes de la cita imperial en Berlín. Por otra parte, el término no era exclusivo de este periódico ni de su ideología: aparece también en periódicos alfonsinos (El tiempo) y carlistas $(L R)$.

80 Pérez Galdós, Benito: La corte de Carlos IV, (E.N. 2), Madrid 1992 [1 1 ed. 1873], cap. IX, pág. 86 (el comentario proviene de Gabriel, pero es acogido con agrado por su interlocutor, que no se percata de la ironía que contiene). 
real, deformada por una pesadilla como la que sueña y vive Segismundo ( $¿ y$ acaso no es Inés, el amor de Gabriel, una hembra Segismundo, que un día se acostará modistilla y se levantará grande de España?). La engañosa luz de las candilejas ilumina todo el episodio: las duquesas juegan a ser actrices, los actores se transforman en personajes; hasta los papeles comprometedores de la conjuración de El Escorial parecen un sainete, y el vil Fernando (alias San Hermenegildo) ataca a sus padres encubriendo sus nombres con los de personajes godos.

Todo el episodio esté lleno de alusiones más o menos directas a Polonia, a su historia, a sus repartos: en las obras que pitan los polacos y jalean los chorizos las actrices representan papeles exóticos de vaga resonancia germánica o eslava, como landgraviata, o archidapífera de país ruso o mongol; el telón nunca se abre sobre una vulgar posada, sino en una gran plaza, donde están formados tres regimientos; en el fondo, la ciudad de Varsovia, a la cual se va por un puente... ${ }^{81}$; hasta los títulos de esas obras suenan a Polonia, o más bien a sus verdugos: El falso Czar de Moscovia, La mayor piedad de Leopoldo el Grande, Pedro el Grande en el sitio de Pultowa, Catalina en Cromstad, Federico II en Glatz... Moratín -nos recuerda Galdós-, queriendo burlarse de sus enemigos, se inventó el título de El gran cerco de Viena, la gesta de Sobieski. Historia y ficción se confunden en el Madrid de Gabriel, como se confunde el sueño y la realidad en la Varsovia de Segismundo: el combate de Trafalgar, que Galdós ha contado en el episodio anterior con gran copia de detalles realistas, apenas se reconoce ya bajo el ridículo título prusiano que lleva el drama dedicado a Gravina: El tercer Gran Federico y combate del $21^{82}$.

El 'marqués', un viejo algo demente, representa lo peor de la diplomacia carolina. Pero como suele ocurrir en la obra de Galdós, la verdad aparece en boca de los orates, aunque mezclada con sartas de disparates que la hacen irreconocible. El marqués tiene manías de grandeza, y se las da de estar al tanto de los planes de las grandes potencias: Por su grandilocuencia, que no era inferior a la flojedad efectiva de su ánimo, servía como objeto de agudísimas burlas entre sus amigos, $y$ en todos los círculos que frecuentaba se divertían oyéndole decir: '¿Qué hará la Rusia? ¿Secundará el Austria tan atroz proyecto? iUn gran desastre nos amaga! iAy de las potencias del Mediodía!' . Galdós se burla de la megalomanía del vejete, que cree a la Europa entera pendiente de sus conflictos con Godoy: no obstante, es precisamente esta ridícula Casandra quien revela lo que se negocia en Fontainebleau y las napoleónicas Especies y cuestiones proponibles. Una vez más, la tragedia polaca está implícita en la mención de las potencias repartidoras: Mis enemigos, que son muchos, han becho correr por toda Europa la especie de que yo llevaba correspondencia secreta con el príncipe de Talleyrand, con el príncipe Borghese, con el príncipe Piombino, con el gran duque de Aremberg y con Luciano Bonaparte, en connivencia con Godoy, para estipular las bases de un tratado por el cual España cedería las provincias

81 Ibídem, cap. II, pág. 21.

82 Ibídem, cap. IX, pág. 84. 
catalanas a Francia a cambio de Portugal y el reino de Nápoles, pasando Milán a la reina de Etruria y el reino de Westfalia a un infante de España. Yo sé que esto se ba dicho —añadió alzando la voz y dando un fuerte puñetazo en la mesa-. iYo sé que esto se ha dicho: ha llegado a mis oídos, sí, señor! Los calumniadores lo hicieron creer a los soberanos de Austria y Prusia; se me interpeló sobre el caso; Rusia no titubeó en bacerse eco de la calumnia, y fue preciso que yo empleara todo mi valimiento y tacto para disipar las densas nubes que se babían acumulado en el borizonte de mi reputación!83.

Preocupada por su reputación y mezquinos intereses, la nobleza española se muestra tan ciega ante las consecuencias de sus acciones como lo había estado la szlachta polaca pocos años antes. Las riñas de polacos y chorizos de los teatros se reproducen en las estancias palaciegas: con tal de derribar al 'choricero' - Godoy-, los polacos de la camarilla fernandina está dispuesta a llegar a cualquier acuerdo con Napoleón. Sólo Chinitas, humilde amolador, vox populi por excelencia (y futuro mártir del 2 de mayo), desconfía del corso: Si [los franceses] cogen a Portugal porque es un reino chiquito, mañana cogerán a España porque es grande. Yo me enfado cuando veo a esos bobalicones que andan por abi: abates, petimetres, frailes, covachuelistas y hasta usías muy estirados que se ríen y se alegran cuando oyen decir que Napoleón se va embolsar a Portugal, y con tal de ver por tierra al guardia [Godoy], no les importa que el francés eche el ojo a un bocadito de España, que no le vendrá mal para acabar de llenar el buche $e^{84}$. A principios de 1873, muchos liberales moderados como Galdós temían que el acoso inmisericorde a la monarquía democrática acarrearía a España consecuencias tan funestas como las que tuvieron en su día aquellas riñas de chorizos y polacos.

\section{EL VístUla Y el EBRo}

En el verano de 1873, el tono de las crónicas de política interior de la Revista de España es el de una revolución. Aumenta la agitación social y la revuelta cantonalista se extiende por el Mediodía; las potencias empiezan a dar señales de inquietud. El 30 de julio de 1873 Castelar pronuncia en las Cortes un discurso en el que rompe con la izquierda de su partido, a la que acusa de impedir la consolidación de la República. Llegan noticias preocupantes de la guerra carlista y de la injerencia estadounidense en Cuba. Los españoles son los apestados de la tierra; una profunda descomposición, gangrena y miseria está matando al país; por fin ha sonado la hora del juicio para España ${ }^{85}$. Las cancillerías se ocupan de

${ }^{83}$ Ibídem, cap. V, pág. 51 y cap. VII, pág. 63. Cfr. supra, acerca de los orígenes del tópico y de su relación con las memorias de Godoy. En otro lugar se explica que en 1792 el marqués estaba agregado a la Embajada española cerca del emperador Leopoldo (pág. 64): eso quiere decir que estaba en la corte austriaca cuando se tramaba el segundo reparto (el único, por cierto, en que 'el' Austria no se aprovechó directamente de 'tan atroz proyecto').

${ }^{84}$ Ibídem, cap. X, pág. 91.

${ }^{85} R d E$, Rpi, tomo XXXII (5.-6. 1873), pág. 408. 
nosotros para explotarnos ${ }^{86}$. El reparto es cuestión de tiempo: los Estados Unidos ambicionan Cuba y Puerto Rico, Alemania se quedará con las posesiones del Pacífico, Francia e Inglaterra ayudarán al pretendiente carlista a cambio de nuevas cesiones territoriales. Entre tanto, la Revista comienza una cruzada en contra de la república federal: Renunciad a esa constitución federal, que si llegara a aprobarse haría un Vistula del Ebro; un Imperio prusiano de nuestras islas Filipinas, una colonia de Washington de nuestra hermosa isla de Cuba, y un país sojuzgado y dividido de esta noble tierra española que tiene la más antigua y gloriosa nacionalidad del mundo ${ }^{87}$.

El día 11 de agosto Fernando León y Castillo toma la palabra en las cortes para pedir la retirada del proyecto de constitución federal. Paisano de Galdós, trabaja a su lado en la Revista; de hecho, es su copropietario, y pronto sucederá al novelista como director. Ese día, su discurso es un ataque frontal al federalismo, pero se dirige sobre todo a Castelar — desde hace unos días en abierta ruptura con los «intransigentes»-, utilizando contra la república los mismos argumentos y tópicos que el orador republicano había utilizado previamente contra la monarquía. León y Castillo le pide que sacrifique a la Patria las ideas que hasta entonces ha defendido: en esta hora suprema de la vida del tribuno - el punto de inflexión en que el ídolo de los republicanos federales se convierte en un republicano antifederal y cada vez menos republicano- su oponente invoca el tópico polaco como principal argumento de su demanda: Si S.S. [Castelar] quiere conservar la unidad de la patria; si quiere decir en el extranjero 'soy español' con el mismo orgullo con que un romano decía 'civis romanus sum'; si quiere que sus buesos descansen en esta tierra, que ba mecido su cuna; si no quiere llorar a la margen de extranjero río las desgracias de la patria dividida, de la patria deshonrada, de la patria perdida; si no quiere condenar a toda una generación a la desdichada suerte de los desdichados hijos de Polonia, que van por Europa mendigando simpatías y sólo han conseguido de la hospitalidad de la Francia un templo para rezar por sus mártires y por sus béroes; si quiere que su nombre, ese nombre respetado en Europa, querido en América, célebre en todas partes; si quiere que su nombre, orgullo de la patria y gloria de la tribuna española, no sea un nombre funesto y quizá maldecido en este país, es necesario que renuncie a la forma federal, es necesario que renuncie a la vanidad pueril de una obstinación académica, es necesario que renuncie a esa Constitución malbadada, sobre la cual, como sobre el sepulcro de nuestra nacionalidad, podría escribirse, recordando a Koskiusko: 'Finis Hispaniae's8.

${ }^{86} R d E$, Rpi, tomo XXXIII (7.-8. 1873), págs. 550-551. Esta cuestión se refleja en las caricaturas de La flaca (cfr. notas 41 y 69). La intervención alemana en el cantón aparece en «Libre España feliz e independiente» (6.8.73): un mapa de España es troceado por personajes de aspecto turbio -internacionalistas - ante la impotencia de Castelar. Bismarck — cuerpo canino, casco prusianoobserva la escena; al fondo, la flota prusiana y los buques apresados.

${ }_{87} R d E$, Rpi, tomo XXXIII (7.-8. 1873), pág. 557 (José Gómez Díez).

88 LeÓN Y CASTILLO, Fernando: Mis tiempos, Las Palmas 1978, tomo I, pág. 106. León y Castillo hace notar que es precisamente este discurso suyo del 11 de agosto de donde Castelar tomaría la 
Es precisamente en este momento cuando se produce ese cambio en la concepción de la política exterior de la República que ya advirtiera LópezCordón $^{89}$ : si desde el fracaso del memorándum de Castelar se ha reprochado la falta de reconocimiento de la república a los prejuicios de la potencias monárquicas - pero, ¿y la hermana francesa? - , en el verano cantonal las acusaciones se vuelven contra el «populacho», contra la «anarquía» de los insurrectos federales - pues es sobre ellos, y no sobre los carlistas, sobre los que recae el peso de la condena-. El cantonalismo ha obrado el milagro de convertir a viejos demócratas y republicanos en acérrimos defensores del orden: se diría que los gobiernos de esta época y quienes les apoyan dan la razón retrospectivamente al Napoleón de 1808. Tantos años después de su ultimátum a la Polonia del Mediodía, han aceptado la idea de que la crisis interna de una nación -l virus interior y corrosivo de sus propios errores - constituye razón suficiente para la intervención del vecino. Ha sido calificado el repartimiento de Polonia por casi todos los bistoriadores de atentado abominable y despojo inicuo, y no seremos nosotros los que combatamos esa casi unánime calificación. Pero sí nos permitiremos observar que la muerte que tuvo la Polonia fue la consecuencia lógica y natural de su estado de permanente anarquía...: así expresa el republicano García Ruiz, que será ministro de gobernación tras el golpe de Pavía, el juicio que le merecen los pueblos díscolos ${ }^{90}$.

Es en esos meses cuando Galdós se dedica a los episodios que narran el comienzo de la guerra de la Independencia: podría esperarse legítimamente que en ellos el liberal exaltara el patriotismo del pueblo en contraste con el servilismo y la cobardía de la corte y la nobleza, y sin embargo, es precisamente aquí donde aparece una de las caracterizaciones más duras y distanciadas de la acción popular de toda la primera serie: el asalto a la residencia de Godoy. Cuando la puerta de la casa se abrió, precipitóse la turba en lo interior, bramando de coraje. Su salvaje resoplido me causaba terror e indignación (...) Era aquélla la primera vez que veía yo al pueblo baciendo justicia por sí mismo, y desde entonces le aborrezco como juez ${ }^{91}$. La paradójica devaluación popular campea ya sobre la portada del tercer episodio, El 19 de marzo y el 2 de mayo, aparecido en plena crisis cantonal de julio. Lo más significativo es esa conjunción copulativa que, cual fiel de balanza, divide el título en sendos hemistiquios. Si lo que se pretende es definir los hitos cronológicos del episodio, ¿por qué no emplear, por ejemplo, una expresión tipo «del - al»? Hay

celebérrima sentencia que el 3 de enero espetará a los partidarios de la Constitución: ila babéis quemado en Cartagena! La mella que las palabras de León y Castillo hicieron en el ánimo de Castelar se advierte incluso en su correspondencia privada (cfr. carta a Adolfo Calzado, 27.1.1874, cit. por Gómez-Ferrer (1983), pág. 399).

89 LÓPEZ-CORDÓN, María Victoria: El pensamiento político internacional del federalismo español (1868-1874), Barcelona 1975, pág. 460 y ss; también Gómez-Ferrer (1983), págs. 361 y ss.

90 García Ruiz, Eugenio: Historias, Madrid 1876, pág. 27.

91 PÉrez Galdós, Benito: El 19 de marzo y el 2 de mayo (E.N. $n^{\circ}$ 3), Madrid 1992 [1 ${ }^{\mathrm{a}}$ ed. 1873], cap. IX, pág. 71-72. Se ha visto, seguramente con razón, un reflejo de los sucesos de Alcoy en esta descripción del motín de Aranjuez. 
algo perverso en el hermanamiento contranatura del motín que empezó con un saqueo y la lucha del pueblo inerme frente a las tropas de Murat.

Ya vimos cómo la captura de la flota cantonal había provocado un temor generalizado a una intervención armada de las potencias. Sin embargo, en 1873 la verdadera amenaza contra la 'integridad territorial' no procedía de ningún cantón, sino de la desobediencia de las prepotentes autoridades cubanas. En noviembre, los fusilamientos del Virginius ${ }^{92}$ estuvieron a punto de provocar una desastrosa guerra con EE.UU (irónicamente, la única potencia importante que había reconocido a la república). No obstante, un historiador republicano como Morayta no dudaba en culpar del proyecto de reparto al que ahora nos referiremos a la situación interior de España y el reverdecimiento de las aspiraciones demagógicas que por la solidaridad de ideas, ballaron calor en los sucesos de Alcoy y de Cartagena... Porque, sí, en 1873 hubo un proyecto, por vago y fugaz que fuera, de convertir realmente a España en la Polonia del Mediodía. Según Morayta, a finales de 1873 el gobierno de Portugal tuvo el atrevimiento de proponer el repartimiento de España, dándose a Inglaterra las Baleares, a Francia las comarcas desde los Pirineos hasta el Ebro, y a Portugal extensos territorios comarcanos a sus fronteras, quedando así reducida España a poco más del antiguo reino de Castilla ${ }^{93}$. Si el tópico polaco es, como creemos, hijo de Tilsit y Fontainebleau, este tanteo luso proporciona a los moralistas un hermoso ejemplo de simetría histórica. Pero volvamos una vez más a la Revista. También allí el círculo se está cerrando. Durante décadas, el tópico polaco había sido utilizado de manera irónica para burlarse de los que un día quisieron doblegar a un pueblo bravo. En 1873 ya no queda un ápice de humor o desafío. Polonia y España se confunden en su agonía: Mucbas veces, al contemplar el espectáculo presente, llegamos a presumir si habrá sonado para España la última hora de su existencia nacional, y si estaremos condenados a ser los últimos hijos de esta Patria sin ventura. iOh, Polonia!, iPolonia!, ipatria de tantos béroes!, ipatria de tantos generosos patricios!, ¿habrá llegado para España el instante aciago de ver proscrita su bermosa lengua castellana, destruidas sus leyes, confiscados sus bienes y profanados sus altares?... ${ }^{94}$.

92 Vid.: ESPADAS BuRGOS, Manuel: «La cuestión del 'Virginius' y la crisis cubana durante la I República», en VV.AA.: Estudios de Historia Contemporánea, Madrid 1976; y Gómez-Ferrer (1983), pág. 388 y ss. No le faltaba razón a un federal cuando decía: Quejábanse muchos de la actitud rebelde, pero lógica, de los cantonales, y no de que las autoridades antillanas, autoridades nombradas por la República, desacataran las órdenes del gobierno. Este babía mandado que no se ejecutara sentencia alguna de muerte sin consultar al poder metropolitano, y en Cuba se continuó fusilando (EsTÉVANEZ, Nicolás: Mis memorias, Madrid 1975, pág. 268).

93 MORAYTA, Miguel: Historia general de España desde los tiempos antehistóricos hasta nuestros días. Madrid 1893-1898, pág. 212; citado por Gómez-Ferrer (1983), pág. 398.

${ }^{94} R d E$, Rpi, tomo XXXIII (7.-8. 1873), pág. 267. Firmada por José Gómez Díez. El subrayado es nuestro.

Hispania, LXII/1, núm. 210 (2002) 167-220 


\section{ASí PASEN CUARENTA AÑoS}

El experimento federal acabó con el golpe del 3 de enero de 1874. Comenzaba una nueva era: tiempos de pragmatismo, de orden y estabilidad. Un ventarrón positivista barre los restos brumosos del idealismo romántico, y con ellos se desvanece también el tópico polaco. De haber escrito su libro unos meses después, es improbable que hubiese aflorado en la obra de Galdós. De hecho, el texto de Zaragoza, en la primavera de 1874, trasluce una expresión de alivio: la permanencia nacional de España está asegurada para siempre (¿habría dicho lo mismo en el verano de 1873?). Ni la República pretoriana — ni menos aún la Monarquía restaurada - aspiran a guiar hacia la libertad a los pueblos oprimidos; pero tampoco temen la inminente desintegración nacional. El espectro de los repartos ha sido conjurado.

Desilusionados por el fracaso de la revolución, los políticos mantendrán durante el siguiente medio siglo una invencible desconfianza hacia la voluntad popular. Pese a su envoltorio parlamentario, pese al sufragio universal (masculino) restablecido en 1890, los partidos dinásticos gobernarán sin confiar en ese pueblo al que ahora culpan de todos los excesos y errores del Sexenio. Este período - pese a sus limitaciones evidentes - aparece en una perspectiva amplia como un paréntesis en medio de un proceso paradójico que dura todo el siglo: la forja de una tradición constitucional y la práctica de su suplantación (Jover). Muy pronto, el 73 ocupará en el recuerdo de los hombres de la Restauración un lugar análogo - guardando las distancias - al que en Francia representa el Quatre-vingt-treize95: así nació el mito del $73^{96}$. Los intelectuales desilusionados por el fracaso de la Federal, utopía popular por antonomasia, volcaron su frustración sobre esos once meses republicanos. Un análisis sereno demuestra la falsedad de muchos de los reproches dirigidos contra las clases populares - en especial, las del cantón de Cartagena-, cuya actuación generalmente pacífica contrasta con las atrocidades cometidas por los ejércitos o las partidas organizadas. En su estudio sobre los orígenes del mito, Jover atribuye un papel importante en su surgimiento y desarrollo a la retórica de Emilio Castelar ${ }^{97}$. No menos importante fue la contribución de Galdós, que en su vejez habría de emprender la ingente tarea de reelaborar en clave progresista el recuerdo histórico del 73. La Restauración había hecho de aquel año paradigma de anarquía: la República federal

95 La novela de Hugo se publicó precisamente en 1873; también en ese momento comienza Taine la elaboración de Les origines de la France contemporaine (1876-1893), revitalizando así la historiografía sobre la gran Revolución. La comparación del 73 español con el 93 francés era tópica en ese momento: Albareda ya identificaba el estado terminal de la monarquía saboyana con la angustia que sobrevino en los últimos días de la constituyente y anticipó el Terror. RdE, Rpi, tomo XXX (1.-2. 1873), pág. 118.

${ }^{96}$ Jover Zamora, José María: Realidad y mito de la Primera República (Del Gran Miedo meridional a la utopía de Galdós), Madrid 1991.

97 Ibídem, pág. 66 y ss.

Hispania, LXII/1, núm. 210 (2002) 167-220 
servía como modelo negativo. La utilización del tópico polaco en versión castelarina en 1874 demuestra que Galdós compartía por entonces esa opinión. Trece años después, el verano de 1873 seguía siendo para él el momento en que la Península, ardiendo por los cuatro costados, era una inmensa pira a la cual cada español había llevado su tea y el gobierno soplaba ${ }^{98}$. Sin embargo, a lo largo de su carrera el escritor experimentó una compleja evolución intelectual que le llevaría a reconsiderar sus opiniones de entonces. ¿Cómo ve Galdós, casi septuagenario, los acontecimientos que vivió en su juventud?

Cuarenta años son suficientes para juzgar con serenidad. En 1874, la mayoría de los que habían apoyado la Revolución de Septiembre creyeron que el orden a ultranza era el último recurso para salvar a la patria del abismo; incluso la vuelta de los Borbones parecía un mal menor, si no una penitencia justa: como si los españoles, incapaces de vivir en libertad, merecieran sujetarse otra vez a aquella dinastía desprestigiada por sus últimos representantes. Sin embargo, el nuevo régimen había degenerado en una farsa. La sociedad española no era tan solo profundamente injusta: además seguía siendo lastimosamente pobre, pues tanta estabilidad sólo había servido para consagrar escandalosas desigualdades. Ni siquiera había evitado el Desastre: en 1898 la monarquía había estado tan falta de apoyos internacionales como lo estuvo la república veinticinco años antes. Desde entonces, los españoles habían vivido aún más conscientes que antes de su decadencia. Los trece años que median entre el 98 y la escritura de los Episodios a los que ahora nos referiremos no fomentaron la esperanza. El sistema bipartidista estaba en quiebra. Las odiosas quintas, contra las que en 1870 se invocara el recuerdo de Zaragoza, seguían siendo cuarenta años después la pesadilla de las clases populares que contribuían con su sangre a la aventura colonial. Durante la Semana Trágica se vieron escenas que superaban el dramatismo del levantamiento cantonal: en 1909, el camino que España había emprendido en 1874 parecía desembocar en un callejón sin salida. En 1898 Galdós había reanudado la publicación de los Episodios nacionales, empezada precisamente un cuarto de siglo antes, en un año que fue, en más de un aspecto, el más claro precedente del Desastre. El estreno de Electra en 1901 le había convertido en el ídolo de la intelligentsia progresista; cinco años después entraba de nuevo en la política activa dentro de la conjunción republicano-socialista. En 1910-1912 el círculo literario se cierra: Galdós (casi ciego) dicta los episodios que evocan los años en que inició su carrera, y rebate la imagen de violencia popular consagrada por la historiografía. De Cartago a Sa-

98 PÉrez Galdós, Benito: Fortunata y Jacinta, Madrid 1988 [1 ${ }^{\text {a }}$ edición: 1886], Cap. I de la $2^{\text {a }}$ parte, pág. 294. Encontramos la misma opinión en los artículos que publica en esa época, en los que afirma que la república que Castelar preconiza es esencialmente conservadora, y, por lo tanto, la única posible; por el contrario, el partido federal de $\mathrm{Pi}$ se apoya sobre una masa anónima, inconsciente y rencorosa, que nos recuerda todas las brutalidades del cantonalismo de 1873. (PÉREZ GALDós, B.: Obras inéditas. Tomo III: política española. Madrid 1923. Págs. 176-7 y 114.)

Hispania, LXII/1, núm. 210 (2002) 167-220 
gunto 99 marca, incluso en su recorrido geográfico, la voluntad de romper con la tradición que concentraba en los sucesos populares del Sur y el Levante toda la carga negativa de 1873: aunque comienza en el agonizante cantón cartagenero, la acción se traslada luego a la guerra del Norte, para acabar - a pesar del título - en Cuenca, lo que permite cerrar la crónica del bienio republicano con una viva descripción de la barbarie carlista durante la toma de esta ciudad en diciembre de 1874. La imagen del Cantón ha sufrido una reelaboración radical: un juicio benévolo sustituye a las tradicionales invectivas. Galdós reconoce la impaciencia y los errores propios de la juventud, la falta de preparación y experiencia, pero es indulgente con el que había servido durante cuatro décadas como espantajo para ahuyentar cualquier intento de reforma. En la descripción de la defensa de las murallas de Cartagena frente a la artillería gubernamental ${ }^{100}$ encontramos un eco familiar: Yo fui también allá para enterarme de cuanto ocurría, y vi actos hermosos que casi recordaban los de Zaragoza y Gerona. Aquel anciano no podía concebir mejor manera de rehabilitar el Cantón que compararlo (o «casi») con Zaragoza ${ }^{101}$.

\section{LOS DOS ASEDIOS}

La fiesta del dos de mayo de 1874 debió ser un jornada dichosa en la vida de Galdós gracias a dos sucesos diferentes, pero unidos por un extraño y casual paralelismo. Aquel día concluyeron dos asedios: uno literario, muy real el otro. Del primero ya hablamos sobradamente: en aquella fecha apareció la versión galdosiana de la gloriosa caída de Zaragoza. El otro acontecimiento estaba destinado a marcar un hito en la historia política de España: precisamente aquel día, el general Concha rompió el cerco que oprimía Bilbao. La «invicta villa» ya había sufrido otros tres asedios durante la guerra de los Siete años; del último había sido liberada en 1836, tras la batalla que dio título a otro Episodio nacional. Así pues, era la cuarta vez que la capital vizcaína resistía a sus sitiadores, y la segunda que su liberación significaba un punto de inflexión en la contienda civil. Aquel fue el último día feliz del Sexenio. Aunque por entonces ya actuaban varias tramas confabuladas para traer la Restauración, el giro de la guerra carlista parecía presagiar al menos la desaparición definitiva de aquella ideología que durante tantos años había lastrado la vida política del país, para que por fin pudiera germinar la simiente del liberalismo, cuya siembra fue aquí tan temprana como lento y raquítico su desarrollo posterior.

99 Pérez Galdós, Benito: De Cartago a Sagunto (E.N. n²45), Madrid 1986 [1 ${ }^{\text {a }}$ edición: 1911].

${ }^{100}$ En 1886 Galdós escribía: Ya se sabe que a Castelar se debió la organización del cuerpo de Artillería y las medidas salvadoras que pusieron fin a la espantosa anarquía de 1873... (en PÉREz GALDós: (1923), tomo III, pág. 112.). Como ha observado Jover, en las páginas de 1911 ha desaparecido ya esa «espantosa anarquía».

${ }^{101}$ Vid. Jover Zamora (1991), pág. 169. Jover, a quien seguimos de cerca en nuestra argumentación, cita la misma frase y la interpreta en un sentido semejante. 
Escribo estas líneas cuando el paso de los años y de provechosas experiencias me ha dado toda la claridad para iluminar el 2 de mayo de 1874, advierte el escritor al comienzo de su evocación (¿se refiere sólo a la victoria de Bilbao? ¿o piensa más bien en la idea de España expuesta en Zaragoza?). El Galdós de 1911 recuerda con dolor las promesas incumplidas, las vanas esperanzas engendradas en aquella gloriosa jornada: no puedo describir el júbilo del vecindario. Era una locura, un delirio. Las aclamaciones abrasaban el aire, infundiendo en las almas el fuego de una nueva vida. Bilbao creía que inauguraba una era de grandeza nacional, de cultura, de emancipación del pensamiento, de todo cuanto podían dar de sí la pujanza mental y la nativa riqueza de aquel pueblo. Al recordar boy los sublimes momentos de aquel día, ayes de gozo, alaridos de esperanza, me parece que oigo burlona carcajada del destino. Sí, sí; porque la Restauración primero, la Regencia después, se dieron prisa en importar el jesuitismo y a fomentarlo basta que se biciera dueño de la beroica Villa. Con él vino la irrupción frailuna y monjil, gobernó el papa, y las leyes teñidas de barniz democrático fueron y son una farsa irrisoria ${ }^{102}$. No, Galdós no sólo habla de Bilbao (aunque tampoco es casualidad que escoja ese escenario para hacer su reflexión): lo que juzga son cuatro décadas perdidas; el mismo desencanto que sintieron los septembristas (que sintió él) en 1874, lo siente ahora el anciano respecto a la Restauración. A esos tiempos bobos dedicará Galdós precisamente la última página publicada de los Episodios; en ella pone en boca de la Madre - de la Historia-, este duro veredicto disfrazado de profecía: Los políticos se constituirán en casta, dividiéndose, hipócritas, en dos bandos igualmente dinásticos e igualmente estériles, sin otro móvil que tejer y destejer la jerga de sus provechos particulares en el telar burocrático. No barán nada fecundo; no crearán una nación: no remediarán la esterilidad de las estepas castellanas y extremeñas; no suavizarán el malestar de las clases proletarias. Fomentarán la artillería antes que las escuelas, las pompas regias antes que las vías comerciales y los menesteres de la grande y pequeña industria. Y por último, bijo mío, verás, si vives, que acabarán por poner la enseñanza, la riqueza, el poder civil y hasta la independencia nacional, en manos de lo que llamáis vuestra Santa Madre Iglesia.

Alarmante es la palabra revolución. Pero, si no intentáis otra menos aterradora, no tendréis más remedio que usarla los que no queráis morir de la bonda caquexia que invade el cansado cuerpo de la nación.... ${ }^{103}$. El Galdós de 1912 - como el de 1874sigue preocupado por el mantenimiento de la 'independencia nacional', pero ya no teme a los prusianos, sino a la Iglesia, y ya no acusa al federalismo, sino a la Restauración, de no haber sabido 'crear una nación'. ¿Y Polonia? No, no hemos encontrado en estos episodios ninguna alusión directa al tópico ${ }^{104}$ : sin embar-

${ }^{102}$ De Cartago a Sagunto, cap. XVIII, págs. 131 y 132.

103 Pérez Galdós, Benito: Cánovas (E.N. nº46), Madrid 1986 [1ª edición: 1912], cap. XXVIII, pág. 180.

${ }^{104}$ Los peligros que tan reales le parecían en 1874 se han convertido en 1910 en ocasión de burla: Viene la cuestión de Cuba. iAb!, ante todo la 'integridad del territorio..., Cuestión elemental, cuestión previa... , bromean Tito y Mariclío en su primer encuentro (en Amadeo I, op.cit. en nota 116, pág. 64). Evidentemente, después del 98 , el peligro de la secesión de Cuba es el único que parece haber

Hispania, LXII/1, núm. 210 (2002) 167-220 
go, sí tropezamos con su nombre. De estas fugaces apariciones de Polonia, unidas por coincidencias que no parecen debidas al azar, quizás pueda deducirse que, después de tanto tiempo, el subconsciente galdosiano seguía asociando misteriosamente los sucesos de aquellos años críticos con la nación eslava. El primero de los casos —en Amadeo I - lo examinaremos más adelante; fijémonos pues en el segundo. Tras asistir a la agonía del Cantón, Tito Liviano viaja al Norte acompañado de Chilivistra, vizcaína irascible y dominadora. Atraviesan el Ebro y se adentran en tierras asoladas por la guerra. A la salida de Vitoria se detienen en una pensión en la que se alojan militares carlistas. La patrona es tan considerada con Tito que despierta los violentos celos de su amante. Una escena perfectamente intranscendente, si no fuera por un detalle: durante la conversación entre las dos mujeres, Tito no entiende nada: y es que la dama, que se llama Polonia, apenas es capaz de articular un castellano macarrónico. Polonia es vasca, y conversa en vascuence con la amiga de Tito, que está empeñada en que su compañero se acostumbre al son del babla nuestra ${ }^{105}$. ¿Casualidad? Puede ser, pero no es ningún misterio el valor simbólico que suele tener la onomástica en la obra galdosiana. Creemos que la aparición de Polonia en la última serie de los Episodios nacionales puede ser la clave que nos conduzca al último avatar del tópico.

sido real en el 73: pero esto es una deformación provocada por acontecimientos posteriores, y no significa que Galdós y tantos otros no temieran realmente durante el Sexenio una catástrofe general, 'polaca', tal como intentamos demostrar en este artículo. De hecho, como hace notar Jover, la evolución intelectual y política de Galdós se aprecia en toda su magnitud precisamente comparando los juicios casi antagónicos acerca de la experiencia republicana que contienen las series inicial y final de los episodios. A nuestro juicio, no pueden extrapolarse sin más al Galdós que trabaja para Albareda en 1871 las opiniones un tanto cínicas del Tito-periodista de esa misma época (que quizás represente al Galdós republicano, cercano al socialismo, de 1910-12, pero desde luego no al joven burgués, liberal conservador, de 1871-74). B.J. Dendle (cuyos puntos de vista sobre la relación entre los primeros E.N. y las crónicas de la $R d E$ compartimos) atribuye la preocupación por la integridad nacional manifestada en los Episodios de esta época a la participación de Galdós en la campaña pagada por los esclavistas cubanos (Cfr. nota 74 ). Sin embargo, hemos visto como esa preocupación no se circunscribía a las Antillas, ni era exclusiva de las publicaciones de Albareda, sino que afectaba prácticamente a todo el espectro político desde los carlistas a Castelar. En definitiva, no podemos compartir su conclusión, basada exclusivamente sobre la clave cubana: Galdós' editorial responsibility for articles supporting repressive Spanish policies in Cuba, and bis defense in the 'episodios' of a national integrity which in its historical context meant opposition to Cuban separatism, make Galdós an accomplice to policies which were to lead ultimately to the disaster of 1898. (DENDLE, Brian J.: "Albareda, Galdós and the 'Revista de España' (1868-1873)", en VV.AA., La revolución de 1868. Historia, pensamiento, literatura. Nueva York, 1970, págs. 362-374).

105 De Cartago a Sagunto, cap. XIV, págs. 109 y ss. Quizás pueda ponerse en relación con la expresión coloquial 'hablar en polaco', o con el significado del término en el argot actual: «catalán». Vid. Oliver, J.M.: Diccionario de Argot, Madrid 1985. 


\section{POLONIA, PATRIA ETERNA}

Recordemos que en la decisiva encrucijada del Sexenio el destino de Polonia servía para advertir del peligro de la desmembración de España: entonces parecía que el mayor riesgo para la unidad nacional provenía de esos excesos del federalismo que iban a hacer un Vístula de nuestro Ebro. El carlismo suponía una amenaza para las instituciones, para la libertad y la modernización de la nación, pero no ponía en cuestión su integridad ${ }^{106}$. Al contrario, los carlistas blasonaban de castizos, y pretendían ser los auténticos representantes de la tradición patria frente a las novedades foráneas de los liberales: una de las pocas contribuciones léxicas del carlismo es 'guiri', un término despectivo que originariamente significó liberal ("cristino»). El pretendiente escogió precisamente un 2 de mayo para entrar en España, con la esperanza de que el país se levantaría en 1872 contra Amadeo como se había levantado en 1808 contra José. Sin embargo, desde la perspectiva del Galdós de 1911, las opiniones de 1874 parecen totalmente erradas. Es cierto que desde finales de siglo la unidad nacional ha sido puesta en cuestión, pero la amenaza no proviene del cantonalismo, sino de las ideologías que han recogido la herencia carlista.

$\mathrm{Al}$ igual que para Galdós, el 2 de mayo de 1874 fue una fecha inolvidable para Sabino Arana. Ese día, mientras el resto de la familia permanecía refugiada en Bayona, su padre pudo contemplar desde las líneas carlistas la derrota de 'la causa'. Aquel disgusto, que le costaría la salud, dejó en él una amargura profunda que heredarían sus hijos ${ }^{107}$. En un artículo famoso - ¿Somos españoles? - Arana imaginaba una conversación entre un bizkaino y un francés sobre la cuestión vasca que terminaba con esta didáctica conclusión: Quedo ahora plenamente convencido de que no es $V d$. español, sino bizcaino. Los polacos nunca se dirán rusos o alemanes, sino polacos... ${ }^{108}$. Un proceso semejante se desarrollaba simultáneamente en Cataluña. En ambas regiones, las reivindicaciones forales del carlismo esta-

${ }^{106}$ La historiografía contradice opiniones tradicionales acerca del patriotismo de unos y el separatismo de otros. Por un lado, a pesar del mito del 73, los cantonalistas nunca hicieron nada semejante a una proclamación de independencia (Vid. prólogo de Jover al libro de PUIG CAMPILlo, Antonio: El Cantón murciano, Murcia 1986 ( $2^{\mathrm{a}}$ ed), págs. XXX-XXXI). Por el contrario, y a despecho de las protestas patrióticas de $L R$ contra los partidarios de la intervención extranjera, los carlistas no dudaron en provocar graves incidentes diplomáticos (p.ej., el caso Schmidt, causa del envío de la flota alemana al Cantábrico en 1874) con tal de poner en aprietos a los gobiernos de Madrid. Lo que dice Salom a propósito de don Carlos en las postrimerías de la guerra no cuadra tampoco con la imagen de patriota que cultivaban sus partidarios: Por este tiempo se respiraba en el 'Cuartel Real' una atmósfera de negro pesimismo, del que sólo parecía escapar el propio Pretendiente, el cual confiaba - según esos informes - en un estallido de la guerra entre España y Estados Unidos (recordemos la tensión creada en estos meses por la iniciativa Fish), en un levantamiento cantonal en Andalucía y en los 'tres generales' - diciembre, enero y febrero- que debian detener a las fuerzas alfonsinas. Salom (1967), pág. 208.

107 JUARISTI, Jon: El bucle melancólico (bistorias de nacionalistas vascos), Madrid 1999, págs. 149-150.

108 ¿Somos españoles? (17.12.93), en ARANA GOIRI, Sabino: El pensamiento de Sabino Arana y Goiri a través de sus escritos: antología de textos, 1893-1903, Bilbao, 1995. Pág. 65. 
ban siendo sustituidas por una nueva ideología nacionalista, capaz de conquistar a una burguesía que desconfiaba del tradicionalismo reaccionario. Poco después de la publicación de Zaragoza, los chicuelos de 1879 bilbaínos, embargados por sus ansias de redención de la patria vasca, ya veían a su tierra como otra Irlanda, Hungría o Polonia. Porque entonces para nosotros (...) estos tres países eran modelo de esclavitud política ${ }^{109}$. También en el Compendi de doctrina catalanista de Enric Prat de la Riba el ejemplo de Polonia servía como demostración de la eternidad y santidad de las patrias: Quina diferència bi ba entre l'Estat i la pàtria? L'Estat és una entitat política artificial, voluntària; la Pàtria és una comunitat històrica, natural, necessària. Lo primer és obra del homes; la segona és fruit de les lleis a què Déu ha subjectat la vida de les generacions bumanes. Quin exemple de la bistòria contemporània fa palpables aquestes diferències? Lo de Polónia. L'Estat polonès morí quan los exèrcits d'Austria, Rússia i Prússia l'esquarteraren; mes Polonia continuà $i$ continua sent l'única pàtria dels polonesos ${ }^{110}$. Nos parece oír el eco de esta otra afirmación: pero su permanencia nacional está y estará siempre asegurada. Lo decía Galdós en 1874, a propósito de España ${ }^{111}$. En esos años se había producido una evolución decisiva en las connotaciones que acompañaban la evocación de Polonia. En 1872, en un momento de desaliento, era la tragedia de su Estado lo que recordaban los nacionalistas españoles. A finales de siglo, era la nación polaca, superviviente pese a llevar más de un siglo repartida entre Imperios de apariencia mucho más sólida que la España humillada en Cavite y Santiago, la que atraía la atención de los nacionalismos

109 Juaristi (1999), pág. 71. Lo dice Unamuno.

110 PRAT DE LA RiBA, Enric, Obra completa, Barcelona 1998 [ $1^{\text {a }}$ edición del Compendi: Sabadell, 1894\}, tomo I, pág. 218. En el opúsculo La question catalane: l'Espagne et la Catalogne. Notice adressée à la presse européenne par la.comité nationaliste catalan de Paris (Idem, pág. 614 y ss.; el folleto original, de azarosa vida, es de 1898) Prat plantea nada menos que el proyecto napoleónico que dio origen al tópico de la Polonia meridional: Mais, s'il [ l'Ėtat espagnol ] continue sa politique traditionnelle, il ne dépendra plus que de la France de faire prédominer le parti annexioniste ou celui de l'indépendance. Et, dans ce cas, si les courants décentralisateurs et fédéralistes qui prennent aujourd'bui naissance en France, acquéraient un développement rapide et se traduisaient par des réformes dans l'actuelle constitution unitaire et centralisatrice de la République française, l'idée annexioniste aurait alors beaucoup de chances de triompher. Une situation, un moment proprice de la politique internationale européenne, et l'annexion serait un fait.

111 Por otro lado, los mismos tópicos sobre la «santidad de las Patrias» se encuentran una vez más en Castelar, sin que falte siquiera el recurso al ejemplo polaco: Es muy difícil matar una nación. El Norte nos ofrece de ello un grande ejemplo. Polonia vivía separada en razas; combatida interiormente por una secular anarquía, consecuencia natural de sus instituciones; y en bora nefasta, creyéndola muerta, se la dividieron en pedazos tres grandes imperios que se ban empeñado en unir las regiones de una nación desmembrada a otros países más fuertes; en dispersar y separar a sus bijos; en arrancar del recuerdo la antigua bistoria, de los labios la antigua lengua, y del suelo hasta las antiguas iglesias donde se conservaba el espiritu de las pasadas generaciones: y a pesar de esos sacrificios en masa, a pesar de esos destierros a Siberia, que recuerdan los destierros de Israel, a pesar de tantos borrores sobre el cadáver de la nación becha pedazos, vive eternamente en su espiritu, el cual envía a su bijos, legiones enteras de desterrados y de mártires, el amor nunca extinguido de la patria. Y aún vive Polonia. Castelar (1875), pág. 166. 
centrífugos. Para los nacionalistas vascos y catalanes ${ }^{112}$, Polonia era un modelo: una nación vital, con una cultura floreciente, capaz de suplir con patriotismo la carencia de un Estado.

Después de 1864 un observador superficial bubiera podido asegurar que Polonia y el polonismo babian dejado de existir, lo mismo que después de 1876 pensaron muchos que ya babia muerto el País Vasco. Pero después de 1864 bubo en la nación polaca un período de trabajo intensivo en condiciones notablemente modificadas. La nación concentró sus energías sobre sí misma, $y$ de esta concentración surgieron profundas transformaciones en la visión misma de las cosas y en el carácter nacional. El centro de gravedad de la vida nacional se trasladó a las capas más profundas, al 'substratum' mismo de la nación, y los elementos populares, basta entonces pasivos, se incorporaron a la vida nacional... Así se expresaba un nacionalista en el diario Euzkadi en vísperas de la Gran Guerra ${ }^{113}$. Este y otros artículos dedicados a Polonia formaban parte de una serie que informaba acerca de las nacionalidades que podían servir de ejemplo al País Vasco, pues en ellas se han realizado y se realizan actualmente labores en todo análogos a los que el vasco debe emprender y proseguir con creciente energía, si desea realmente que su antiquísima nacionalidad sea conservada entre los pueblos vivos, sin llegar a ocupar un puesto en la lamentable necrológica de las naciones ${ }^{114}$. Aunque se incluían nacionalidades tan diferentes como la albanesa o la nipona, Polonia e Irlanda eran los ejemplos que más interesaban al periodista. La comparación de la represión del levantamiento de 1863 con el fin de la última guerra carlista mostraba que los vascos debían olvidar el legitimismo para emprender una vía de construcción nacional centrada en el concepto racial: el título, países y razas, indicaba desde la portada la ecuación básica del nacionalismo sabiniano. Era en el pueblo, y no en la intelectualidad o en la nobleza, donde se encontraba la verdadera esencia nacional, decía Eleizalde en referencia a la aristocracia polaca, pero pensando seguramente en los carlistas. La tarea fundamental de los nacionalistas era defender la cultura indígena amenazada por el 'exotismo' oficial: Por esa razón, mientras Polonia pueda oponer a la cultura oficial una cultura indígena capaz de rivalizar con aquella, la existencia de la personalidad nacional de los polacos está asegurada, cualesquiera que sean los manejos del gabinete de Berlín y del pangermanismo. El maestro y el judío son las armas de las que se vale Prusia para absorber a Polonia - los equivalentes, cabe decir, del maketo- pues en la Polonia actual, como en la Euzkadi de la Edad Media, como en todas partes, el odioso BeniIsrael guarda fielmente su puesto y hace su papel constituyéndose en espontáneo y eficaz auxiliar de los opresores contra la nación que soporta el parasitismo bebraico ${ }^{115}$.

112 Y seguramente también para los gallegos, entre los que encontramos un precedente precoz. Antolín Faraldo, precursor del galleguismo, ya atribuía en 1845 los males de Galicia a un destino terrible e inexorable: la desgracia que pesa sobre el pueblo de O'Conell y sobre los hermanos de Kociusko.... En ElorZA, Antonio: y LÓPEZ Alonso, Carmen: Arcaísmo y modernidad. Pensamiento político en España, siglos XIX-XX, Madrid 1989, pág. 155)

113 ELEIZALDE, Luis de: Países y razas: las aspiraciones nacionalistas en diversos pueblos (1913-1914); Bilbao 1914, pág. 59.

114 Ibídem, introducción, pág. IV.

11 Ibídem, págs. 65-66.

Hispania, LXII/1, núm. 210 (2002) 167-220 
Evidentemente, el nacionalismo polaco ofrecía un magnífico modelo para los separatismos peninsulares. Pero, ¿̇influyó además de alguna otra manera el tópico polaco en la evolución ideológica de los nacionalismos vasco y catalán, tal y como había sucedido en el Sexenio con la del nacionalismo español? A nuestro juicio, la respuesta a esta cuestión es afirmativa. Y además permite explicar una de las características más sorprendentes del nacionalismo vasco (y, en menor medida, del catalán): su acento en la identidad religiosa. Pero antes acudiremos a una última cita con Galdós.

\section{LA RePÚblica Hispano-Pontificia}

Como ya advertimos, hay otra curiosa aparición del nombre de Polonia en los últimos episodios. El fragmento del que nos ocupamos ahora pertenece a Amadeo $~^{116}$. Tito Liviano, periodista donjuanesco y republicano, es poco menos que raptado por su padre carlistón, y arrastrado hasta Durango, donde vive a la sazón la familia. El padre está empeñado en que Tito siente cabeza y se case con una hija del país: una campesina ruda, tan cerrada en el babla vascuence que apenas podía decir en castellano frases premiosas, trabucando los casos, descoyuntando la sintaxis como lo harian los mismos demonios, y cuyos padres se podrían presentar como maniquies de tipo eúskaro en un museo etnográfico ${ }^{117}$. Facunda, que posee cuatro caseríos, dos de ellos en Santa Polonia, lo más hermoso de la vega de Durango, le resulta antipática desde el principio por el brutal fanatismo que percibe en ella. Un día, cuando los prometidos caminan desde Durango basta Santa Polonia ${ }^{118}$, Tito intenta propasarse; la mujerona lo derriba con facilidad y lo ridiculiza durante el resto del paseo hasta Santa Polonia: la formidable burla de la que nos ocuparemos a continuación es precisamente la venganza de Tito por esta humillación. Este pasaje guarda ciertas semejanzas con el otro en el que también aparece el nombre de Polonia: en ambas ocasiones la anécdota transcurre en tierras vascas, en un ambiente carlista, y la mujer relacionada con Polonia tiene dificultades para expresarse en castellano; además, Tito acabará en ambos casos

116 PÉrez Galdós, Benito: Amadeo I (E.N. n²43), Madrid 1987 [1ª edición: 1910], cap. IV y V. En este episodio Galdós habla de su pasado como periodista en las publicaciones de Albareda; por primera vez, el autor aparece fugazmente como personaje, oculto bajo la denominación del «isleño» (Cfr. nota 104).

117 Ibídem, cap. XVI, págs. 114-5. En este noviazgo de Tito y la campesina de rotundo apellido y modélicos orígenes eúskaros podría verse una alusión burlesca al matrimonio de Sabino Arana con Nicolasa Achica-Allende y sus 126 apellidos euzkéricos.

118 Ibídem, cap. XVI, págs. 116. Hemos comprobado que existe tal topónimo en las cercanías de Durango (en VV.AA., Nosotros los vascos / Ama lur: geografía física y bumana de Euskal Herria, San Sebastián, 1998-1999, t. III, pág. 409).

Hispania, LXII/1, núm. 210 (2002) 167-220 
golpeado y humillado por una hembra ${ }^{119}$. Esta vinculación entre la expresión y el País Vasco nos servirá para interpretar una escena inmediatamente posterior, que es además, según nuestra modesta opinión, una de las cumbres literarias de esta serie.

Obligado a hablar ante un auditorio carlista, Tito concibe un avieso plan para reírse de los durangueses. Tras ponderar la pureza la tierra vasca y la belleza de su lengua - la más antigua y la más bermosa del mundo-, y anunciar que la causa de Dios triunfará en Vasconia, y en Vasconia tendrá su principal asiento, cabeza de todos los reinos católicos de nuestra España, no se le ocurre mejor idea que atacar a los reyes de cualesquiera legitimidad, ramas una y otra de un árbol podrido. Ante el estupor del público, Tito lanza su «bomba»: Sí, hermanos queridos, la república es nuestra salvación. Entonces, cuando parece que el orador no conseguirá salir vivo de la sala abarrotada de fanáticos carlistas, Tito especifica que la República que propugna no es aquella bacante semi-desnuda y escandalosa, bija de Satán, que trastorna con su bello nombre y su infernal doctrina a los pueblos y ciudades de Castilla, sino... la Iglesia católica. Durangueses, pueblo todo vasco-navarro, derribad los ídolos dinásticos, usurpadores de la autoridad, y poned en el trono vació la excelsa soberanía del Papa... Ganado el entusiasmo de sus oyentes, Tito explica burlonamente su proyecto de República Hispano-Pontificia: Pío IX será rey, un Concilio permanente sustituirá al Congreso y al Senado, mientras que el clero asumirá las tareas administrativas ${ }^{120}$.

El significado simbólico de Santa Polonia como destino del accidentado paseo de Tito está subrayado por el simbolismo de la propia Durango. Efectivamente, no es casualidad que Galdós haya elegido esta villa como escenario del discurso. Al final de su perorata, Tito regala a sus oyentes una nueva burla: les revela que una pieza fundamental de su proyecto es el restablecimiento de la dulce Inquisición: Sí, la llamo dulce porque sus efectos nos llevarán a un dulcísimo estado de beatitud, porque los rigores que a veces empleará contra la berejía son cosa blanda en parangón de la paz y dulcedumbre que ha de dar a la nación... Esta apología del Santo Oficio provoca delirio, palmoteo frenético, berridos de aldeanos, lloriqueo de señoras... ${ }^{121}$. La descripción de este entusiasmo no estaría cargada de ironía en nin-

119 Muchos autores han insistido en el papel fundamental desempeñado por la mujer vasca en el movimiento nacionalista: Desde entonces han sido las mujeres junto con los curas, los grandes difusores del nacionalismo vasco (...) las mujeres vascas, las 'emakumes', acunaron el sentimiento de amor a Euskadi, baciéndose insustituibles en su papel de ideologización política y prestando con naturalidad el gran símbolo materno a la idea de la patria vasca. GARCíA DE CORTÁZAR, Fernando: El nacionalismo vasco, Madrid 1999, pág. 57). En la narrativa de Galdós no son excepcionales los personajes femeninos caracterizados por la violencia y el fanatismo; suele tratarse de mujeres carlistas: sería interesante seguir la pista de este modelo desde la Doña Perfecta de 1876 a la María de las Nieves de 1911 (en el episodio conquense de De Cartago a Sagunto).

120 Amadeo I, cap. XVII, págs. 119-129.

${ }^{121}$ Ibídem, pág. 125-126. En 1910 el topónimo estaba de moda debido a un triste suceso: una exhibición aérea en Santa Polonia acabó con un motín del público y el incendio de las instalaciones 
gún otro lugar de Vizcaya que no fuera Durango: pues el nombre de la villa estaba unido al recuerdo de la secta herética de Alonso de Mella, duramente reprimida por la Inquisición episcopal en 1442. De los «herejes de Durango» hablaba Menéndez Pelayo en su Historia de los Heterodoxos, donde reproducía la carta de un corresponsal vasco que le comunicaba que el estigma se mantenía hasta la fecha (1890): La señal que Alfonso tenía para reunir a los sectarios era el sonido de la trompa... Durango desde entonces, y con motivo de los herejes, fue y es llamado en son de burla por los pueblos comarcanos el pueblo de las trompas... ${ }^{122}$. Esa era la cruel paradoja del discurso: los durangueses, descendientes de víctimas del fanatismo religioso, se entusiasman ante la idea de restablecer la Inquisición; de ahí que Tito en su huida piense entre sueños que Torquemada, con sus bórridas bogueras y sus crueles suplicios, era más humano que la bestial plebe duranguesa.... ${ }^{123}$. Algunas referencias del discurso, como el despojo de Pío IX o la expulsión de los religiosos, aluden a circunstancias del momento en que transcurre la acción, la primavera de 1872 , aunque en este último caso, la propuesta de abrir las fronteras a los religiosos expulsados puede interpretarse también en el contexto histórico en que escribe Galdós: el año de la Ley del Candado. Esa cuestión aparece obsesivamente a lo largo de todo el episodio, hasta el punto de resumir la Regencia en esta provocadora simplificación: se fueron las colonias y entraron a comer manadas frailes y monjas ${ }^{124}$. En cualquier caso, varios indicios nos permiten deducir que el verdadero objeto de burla del discurso de la República HispanoPontificia no es tanto el carlismo del Sexenio - moro demasiado muerto en 1910 como para merecer tan gran lanzada-, como el nacionalismo vasco de principios de siglo.

Al conocer la retirada del pretendiente, un cura carlista advierte: En el siglo $X X$ resucitaremos (...) Resucitaremos los soldados de la fe para traer a España el Reino de Dios ${ }^{125}$. El mensaje es que el carlismo, aparentemente vencido tras la última guerra, ha retoñado convertido en otra cosa. La escena de Durango adquiere así un doble sentido que revela una amargura oculta bajo la aparente jovialidad: Tito — burlador burlado- cree reírse de los carlistas, pero en realidad su pastiche de oratoria político-sagrada anticipa el núcleo de la doctrina sabinia-

del aeródromo. Así pues, el carácter 'brutal' de la 'plebe duranguesa' y su afición a las hogueras debía ser un tema de actualidad en el momento en el que escribía Galdós.

122 Menéndez Pelayo, Marcelino: Historia de los heterodoxos españoles, México, 1983 [ 1 a edición: 1880], vol. I, nota págs. 357-358. Tengo motivos para creer que la ironía puede ser una broma privada de Galdós a Menéndez Pelayo. Varios pasajes de anacronismo evidente - la narración transcurre en 1871 - permiten suponer un guiño cómplice dirigido al amigo, como cuando se nos dice que en aquella casa venerable [la Academia de la Historia] suele entretenerse [Clío] ayudando al conserje en el barrido de la biblioteca... Si le anochece en esta faena suele quedarse a dormir en la portería, y por la mañana le cepilla la ropa al gran don Marcelino, por quien siente ardoroso cariño maternal... (Amadeo I, pág 68; también en pág. 171).

${ }^{123}$ Amadeo I, cap. XIX, pág. 139.

124 Ibidem, cap. V, pág. 38.

125 Ibidem, cap. XVI, pág. 118. 
na: un carlismo sin rey, que conserva lo que Galdós consideraba la quintaesencia del movimiento, el «fanatismo», el clericalismo integrista. Por eso la Madre - la Historia - califica el discurso de profecía burlesca ${ }^{126}$ : en realidad, el discurso es una sátira del ideal aranista, la perfecta armonía y conformidad entre el orden religioso y el político, entre lo divino y lo bumano que expresa el lema Jaungoikua eta Lagizarra.

En la primera década del siglo, Galdós, amigo de Pablo Iglesias, está más cerca que nunca del socialismo. La inmigración obrera ligada al auge industrial de Vizcaya - la 'invasión maketa' - ha provocado una reacción xenófoba que se manifiesta plenamente en la ideología de Arana. Un agudo conflicto enfrenta al socialismo - que en estos años es profundamente internacionalista- con el nacionalismo vasco: desde la perspectiva de este último, el socialismo maketo representa la quintaesencia de lo antivasco ${ }^{127}$. La tensión entre ambas ideologías se refleja en la oposición nacionalista a las huelgas obreras: a raíz de la 1910 - fecha del discurso de Durango- surgirá incluso un sindicalismo nacionalista dirigido específicamente contra el socialismo, arma de exotismo y desvasquización ${ }^{128}$. Entre tanto, los vasquistas consiguen los primeros puestos de responsabilidad gracias a la colaboración con otras fuerzas de derecha: en 1907 un nacionalista preside el ayuntamiento de Bilbao, donde Facundo Perezagua -enviado por Iglesias como organizador del socialismo vasco- es concejal. En 1909, en pleno acmé de la ola anticlerical que culmina en la Semana Trágica, el nacionalismo vasco subraya aún más su carácter confesional con peregrinaciones marianas, mezcla de política y devoción que recuerda el legitimismo francés de la década de 1870. La oposición a la política liberal de Canalejas, y en particular a la ley del Candado, será una de las bazas electorales y propagandísticas de los nacionalistas en esos años. Su integrismo, rasgo que comparte con el resto de la derecha vizcaína, provoca una reacción que confiere al socialismo bilbaíno una característica que le distingue del de otras provincias: un marcado anticlericalismo ${ }^{129}$ que tan bien concuerda con el ánimo del Galdós de la última serie de los Episodios nacionales, sin duda alguna la más anticlerical y 'bilbaína'. El discurso de la República Hispano-Pontificia ${ }^{130}$, venganza de Tito

${ }_{126}$ Ibidem, cap. XVIII, pág. 132. Toda la escena de Durango tiene por lo demás un claro trasfondo mitológico: en realidad, Tito - cuyo verdadero nombre es Proteo- no hace sino representar el papel que le tenía asignado la mitología clásica. A este dios marino le había sido concedido el don de la profecía, pero se negaba a utilizarlo; cuando alguien intentaba arrancarle una predicción, Proteo cambiaba de forma para evitar dar una respuesta. También Proteo Liviano es obligado a dirigirse a los durangueses; también él intenta zafarse adoptando un disfraz -ideológico-, y termina, como era de esperar, haciendo -malgré lui - una profecía genuina.

127 CORCUERA ATIENZA, Javier: Orígenes, ideología y organización del nacionalismo vasco (18761904). Madrid 1979, pág. 258 y ss: 'Los socialistas'.

128 García de Cortázar (1999), pág. 48.

129 Fusi, Juan Pablo: Política obrera en el País Vasco, 1880-1923. Madrid 1975, pág. 221 y ss.

130 Para explicar la expresión que da título al discurso vendría bien recordar que la palabra «república», referida a los territorios vascos, formaba parte del lenguaje nacionalista: se utilizaba para 
por la humillación sufrida 'en el camino de Durango a Santa Polonia', nos conduce al final de nuestra reflexión. Una coincidencia ciertamente sorprendente vincula al nacionalismo vasco con el polaco: la identidad religiosa como seña diferencial de la nación.

\section{No CATÓliCOS, SINO CATÓLICOS}

Volvamos a 1872, el año del centenario: como vimos a través de la prensa carlista, el tópico polaco estaba entonces íntimamente ligado a la expulsión de los jesuitas del Reich, a la persecución del clero de Poznan, al Kulturkampf, incluso a una supuesta conjura para acabar con el papado. En aquellos años, la prensa usó y abusó del «martirio de Polonia» para advertir a la iglesia española de una inminente persecución. Un artículo titulado La descatolización, aparecido en 1874 en una publicación tan poco sospechosa de neocatolicismo como la Revista de España, arremetía contra la impía y perversa tarea que sólo parece fraguada en los antros. del Averno, y cuya inmensa responsabilidad alcanza a nuestros más conocidos probombres contemporáneos; [...] que el Czar de todas las Rusias martirice con toda clase de inicuas vejaciones a los católicos o a las instituciones católicas de la infeliz Polonia, o que el canciller prusiano, en su triste omnipotencia, sacrifique a los obispos y pueblo y clero indoblegables a su maquiavélica diplomacia son lógicas cosas, pero [que suceda] aquí es una monstruosidad del demonio. Concluía con esta temeraria afirmación: Así es como el catolicismo es perseguido por igual en España, y en Polonia y en Prusia ${ }^{131}$.

Durante el Sexenio, la faceta religiosa del tópico polaco se justificaba, al menos en teoría, porque los gobernantes - casi siempre católicos- solían ser hostiles al ultramontanismo (aunque, desde luego, jamás persiguieran a los católicos como en Polonia y en Prusia). Pero a finales de siglo el Sexenio es historia antigua. En un Estado católico que escandaliza a Europa por la falta de libertad religiosa; bajo un régimen que concede refugio a los clérigos expulsados de Francia y Portugal; con una dinastía que hace alarde de religiosidad y aun de beatería; en el seno de una sociedad levítica, en la que la Iglesia conserva una cuota de poder social y económico inimaginable en otros países católicos; en un momento en el que se multiplican las fundaciones religiosas y las donaciones, en el que se exalta el recuerdo de la Reconquista para justificar la agresión a Ma-

subrayar su presunta independencia histórica respecto a los reinos de los que formaban parte. Por otra parte, el fin del aislamiento de los nacionalistas vascos en 1903 se relaciona con su apoyo a la 'política vaticanista' de José María de Urquijo; en las elecciones municipales de noviembre los nacionalistas obtuvieron en Bilbao un importante triunfo gracias precisamente a la política de «bloque católico» (Cfr. supra, texto de Galdós sobre la 'invasión frailuna': "gobernó el papa...»). Por último, podría haber también una alusión irónica al último proyecto de Arana: la Liga de Vascos españolistas. Vid. Corcuera (1979), pág. 498 y ss.

131 Marín Palomo, Manuel: «La descatolización», RdE, tomo XLI (Madrid, 11.-12. 1874), pág. 60 y ss. 
rruecos... ¿cómo explicar que frente a semejante régimen el nacionalismo vasco haga del catolicismo una — si no la prinçipal— de sus señas diferenciales de identidad?

La mayor parte de Polonia estaba repartida entre dos imperios hostiles a la Santa Sede; incluso en el caso de Austria podía aducirse un matiz religioso diferente, pues el gobierno y una parte del clero austríacos seguían la tradición josefista. Nada parecido ocurría aquí, donde no había diferencia confesional alguna entre las regiones, ni se podía hablar de persecución - ni siquiera de hostilidad - de las autoridades contra la Iglesia. Pero en la década de 1870 carlistas y neocatólicos habían exaltado la persecución de los católicos polacos, interpretando literalmente el título de «nación mártir» que hasta entonces le habían dispensado los liberales en sentido figurado, en homenaje al sacrificio del pueblo en aras de la libertad. En ese sentido «liberal» hablaba Galdós de martirio en 1874, cuando justificaba la permanencia de España frente a otros pueblos [que] sucumbian por el sacrifico de la sangre y vida de los zaragozanos, que consagraron la independencia española como consagraban los mártires en el circo la idea cristiana. Lo que en Galdós es una simple comparación, en la prensa religiosa es una identificación completa ${ }^{132}$. Para los hermanos Arana, procedentes de un ambiente clerical, educados en colegios de la Compañía, la idea de que una nacionalidad oprimida debía ser perseguida y martirizada en razón de su fe debía ser una obviedad: no habría nación si no había martirio. El vasco no sólo tenía que ser católico, sino católico perseguido, y a ser posible martirizado ${ }^{133}$.

Para suplir la falta de tensión religiosa entre los vascos y el resto de los españoles, Arana recupero una idea algo envejecida a finales de siglo, pero muy de moda en los tiempos de Sadowa y Sedán: la que atribuía a cada raza cierta predisposición religiosa ${ }^{134}$. Su concepto de nación descansa sobre la idea de un sustrato racial absolutamente original: los vascos son el Urvolk europeo, anterior a todos los demás pueblos del continente y una verdadera isla en medio de la bumanidad, en tanto que la raza española es... un producto latino-gótico-arábigo con tenues toques de fenicio, griego y cartaginés, que no conserva ni rastro de la raza primi-

132 En Castelar abundan las comparaciones entre los polacos mártires de los cosacos y los mártires de las catacumbas: por ejemplo, en Castelar (1881), op.cit., pág.50. Es probable que también en este caso Galdós se inspirara en su oratoria.

133 Caro Baroja cita esta expresiva frase coloquial: Parece mentira que Fulano, siendo vasco por los cuatro costados, sea tan poco religioso. (CARO BAROJA, Julio: Los vascos, Madrid 1995, pág. 268). Acerca de la retórica martirial del nacionalismo vasco, resulta esclarecedor el estudio de JUARISTI, Jon: Sacra Némesis. Nuevas historias de nacionalistas vascos, Barcelona 2000, en especial el capítulo 'Stavrogin', pág. 105 y ss.

134 Según esta teoría, los latinos propendían al catolicismo y las germanos a la Reforma; por eso se suponía también que debía haber alguna diferencia racial entre polacos y eslavos ortodoxos. Arana acude también al factor racial para atacar a sus enemigos dentro del clero. Por ejemplo, para explicar que algunos jesuitas critiquen el vasquismo: la razón es la diferencia de raza (ARANA GOIRI, Sabino: Obras completas, Bilbao 1990, tomo I, pág. 1738). 
tiva de la península, que fue la nuestra ${ }^{135}$. En Euskadi, la raza permaneció pura gracias a los estatutos de limpieza de sangre que Arana proponía reinstaurar en forma de «leyes raciales». La pureza racial se confundía con la pureza religiosa: las razas árabe y bebrea habianse ya enlazado con la española, inculcándole el virus anticristiano, y judios y judaizantes babía numerosísimos en la nobleza española, y judíos y judaizantes hasta en el clero y en los mismos conventos ${ }^{136}$. La religión formaba parte de la herencia racial vasca; y si la raza vasca era diferente de la española, entonces también tenía que serlo forzosamente su religión. Por eso mismo, lo que caracteriza la invasión maketa (Los maketos. Esos son nuestros moros.) es la impiedad (La impiedad es maketa), transmitida seguramente por el «virus» semita que los españoles llevan en la sangre. Los campesinos vascos son religiosos, castos, y sólo bailan danzas sin contacto físico entre los sexos, mientras que los maketos son impíos, lujuriosos, blasfemos, y practican el baile agarrao: el malogrado romance de Facunda y Tito (de una Iturrigalde y un Liviano) ilustra su incompatibilidad racial y moral.

La conclusión es que Bizkaia, dependiente de España, no puede dirigirse a Dios, no puede ser católica en la práctica ${ }^{137}$. Instaurare in Christo Euskeria es el lema adoptado por el clero vasco-navarro afecto al ideal sabiniano (e ignaciano) de subordinación de lo civil a lo religioso ${ }^{138}$. Una de las primeras reivindicaciones nacionalistas será la constitución de una provincia eclesiástica propia: es decir, la «independencia» del clero vasco. El artículo No rezan con nosotros - el integrista Sabino roza el cisma predicando un particularismo nada católico - plantea una nueva versión religiosa del tópico polaco. Solo que ahora Polonia ya no es el modelo de España, sino del País Vasco: Dominada y destrozada está Polonia por Rusia, Alemania y Austria, y sin esperanzas tal vez de restaurarse, y no obstante posee su Iglesia propia. ¿ Por qué, pues, Euskeria, dominada por Francia y España, no ba de tener la suya, independiente de estas naciones? ${ }^{239}$. En 1894, veinte años justos después del final del asedio literario de Zaragoza y del sitio real de Bilbao, el manifiesto fundacional del Círculo Euskariano (Euskeldun Batzokija) establecía que Bizkaya será católica-apostólica-romana en todas las manifestaciones de su vida interna y en sus relaciones con los demás pueblos, al tiempo que prohibía la blasfemia,

135 ARANA GOIRI, Sabino: El pensamiento de Sabino Arana y Goiri a través de sus escritos: antología de textos, 1893-1903, Bilbao, 1995. Pág. 65.

136 «Ley de raza» (1897), en ARANA GOIRI, Sabino: Obras escogidas: antología política, San Sebastián 1978, págs. 201-202. Sobre la influencia del antijudaísmo tradicional en los nacionalismos ibéricos, Vid. JuARISTI, Jon: Vestigios de Babel. Para una arqueología de los nacionalismos españoles, Madrid 1992. Aunque el autor de Gloria no sirva precisamente como ejemplo de antisemitismo, es justo recordar aquí que en la asediada Zaragoza solo un traidor rompe la unanimidad heroica: el tío Candiola, «judío mallorquín».

137 «Efectos de la invasión» (1897), Ídem, pág. 69 y ss.

138 GARCía DE CORTÁZAR, F.: «Iglesia vasca, religión y nacionalismo en el siglo XX», en FUSI, Juan Pablo y GARCÍA DE CORTAZAR, Fernando: Política, nacionalidad e Iglesia en el País Vasco, San Sebastián, 1988, pág. 65.

139 «No rezan con nosotros» (1894), en Sabino Arana (1978), pág. 82. 
los cantares impíos y obscenos, los juegos de azar y los cantos genuinamente españoles ${ }^{140}$. Euskadi sería pues una teocracia: no es casualidad que la estrepitosa caída de Sabino en su camino a Damasco - una conversación fraterna convirtió al Saulo carlista en el Paulo del nacionalismo- se produjera un Domingo de Resurrección, la fiesta en que se celebra el Aberri Eguna. Una de las razones por las que Eleizalde se extendía tanto al hablar de Polonia era precisamente el papel que su clero había desempeñado en la conservación del espíritu nacional, en contraste - afirmaba - con una triste nación, cuyo clero (salvas egregias excepciones), parte por ignorancia, parte por otra causa, se convierte en el más eficaz agente de desnacionalización ${ }^{141}$. También merecía todos sus elogios la postura de la minoría polaca en el Reichstag que se negaba a dejarse absorber y manipular por el partido católico alemán, el Zentrum, los mauristas de por allá142. Por entonces se discutía entre los nacionalistas partidarios de la pureza a todo trance y los que estaban dispuestos a pactar con otras fuerzas de derechas para hacer frente al avance del voto obrero. No deja de ser irónico que poco más tarde fuera elegido un diputado nacionalista en Navarra con el apoyo de los mauristas 'de acá'143.

Y así, calcados sobre un supuesto modelo polaco, crecerán en la España traumatizada por el Desastre unos nacionalismos centrífugos construidos sobre una extraña paradoja: los partidarios de la independencia respecto de uno de los Estados más católicos, de una de las sociedades más clericales, empuñaron el lábaro como símbolo de rebeldía. La anomalía se haría aún más evidente después de la Cruzada. En los turbios años del «nacionalcatolicismo», convertida España en reserva espiritual de Occidente y vanguardia de la civilización cristiana ${ }^{144}$, los seminarios, los colegios religiosos y los santuarios marianos desempeñarían en el País Vasco, y aun en Cataluña, un papel análogo al que les había tocado representar un siglo antes en la lucha de Polonia por su independencia.

\footnotetext{
140 Reglamento del Euskeldun Batzokija, 1894. Elorza y López Alonso (1989), pág. 153.

141 Eleizalde (1914), pág. 77. En 1923 el director del Euzkadi sería excomulgado por criticar un discurso del cardenal Benlloch. Vid. García de Cortázar (1999), pág. 69.

142 Eleizalde (1914), pág. 67.

143 García de Cortázar (1999), pág. 51.

144 Por supuesto, no todo el clero vasco era vasquista. Entre los españolistas cabe destacar por su relación con Polonia a Zacarías de Vizcarra, ideólogo del 'panhispanismo'. Este sacerdote vasco residente en Argentina trabajaba en 1938 como asesor de.la Nunciatura en Varsovia, y tomaría del régimen de Pilsudski algunos rasgos (en especial, su aversión al comunismo ruso). También escribió una Vasconia españolísima (1939), en la que el acendrado catolicismo vasco se utilizaba como argumento a favor de su hispanidad. Vid. BotTI, Alfonso: Cielo y Dinero. El nacionalcatolicismo en España (1881-1875), Madrid 1992, pág. 82 y ss.
} 